Samuel H. Baker*

\title{
Aristotle on the Nature and Politics of Medicine
}

https://doi.org/10.1515/apeiron-2019-0052

Published online October 19, 2020

Abstract: According to Aristotle, the medical art aims at health, which is a virtue of the body, and does so in an unlimited way. Consequently, medicine does not determine the extent to which health should be pursued, and "mental health" falls under medicine only via pros hen predication. Because medicine is inherently oriented to its end, it produces health in accordance with its nature and disease contrary to its nature-even when disease is good for the patient. Aristotle's politician understands that this inherent orientation can be systematically distorted, and so would see the need for something like the Hippocratic Oath.

Keywords: Aristotle, medicine, politics, medical ethics, Hippocratic Oath

\section{Introduction}

We have good reason to believe that Aristotle carefully reflected upon the nature of the medical art and its role in the political community. Having observed medical practice at a young age since his father "traced his family and his art back to Machaon, the son of Asclepius,"1 Aristotle went on to write groundbreaking biological treatises, which often have medical implications, ${ }^{2}$ and he frequently uses the example of "art" (technē), especially the medical art, when expounding his

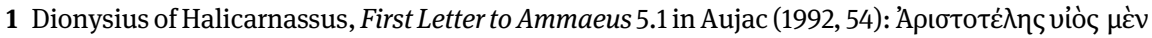

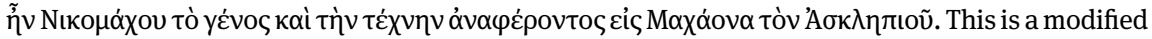
translation from Natali $(2013,8)$, who also presents other evidence that Aristotle was from a medical family.

2 See van der Eijk (1999, 492-4), who gives reasons to think that Aristotle also wrote specifically medical treatises, many (if not all) of which have been lost.

*Corresponding author: Samuel H. Baker, Philosophy Department, University of South Alabama, 5991 USA Dr. N., Room 124, Mobile, AL, 36688, USA, E-mail: samuelbaker@southalabama.edu. https://orcid.org/0000-0001-9168-1523 
philosophical views. ${ }^{3}$ Aristotle also plainly states that political wisdom rules over every art ( $N E$ I 2, 1094a24-b7), he observes that the medical art is in danger of being distorted ( $P o l$ I 9, 1258a6-14), and he assumes that doctors should give an account for the way they use their expertise (Pol III 11, 1282a1-3).

In this paper, I reconstruct Aristotle's account of the medical art with a view to appreciating its political consequences. ${ }^{4}$ My method will be synoptic since in order to present a suitable reconstruction, I must weave together many remarks scattered throughout the corpus. The style will in turn be compendious because my method will sometimes require me to forgo extended exegesis and to make some interpretative decisions without fully defending them. ${ }^{5}$ Yet the result will be a philosophically subtle account of medicine that is a defense of common sense with nontrivial implications: for example, since the doctor is essentially a kind of healer, any doctor who used the medical art to produce disease, would be acting contrary to the nature of that art-even if the patient wished to be diseased and even if the patient would be better off diseased.

According to Aristotle, the end of the medical art is health (Section 2), which is a certain bodily virtue (Section 3). Health is a necessary precondition for happiness, but it is not a part of happiness; consequently, even though the medical art pursues health in an unlimited way, this pursuit may be limited by subordination

3 See Fiedler (1978, 180-3), who observes that the medical art plays a special role in the exposition of Aristotle's philosophy, and that it is particularly used to clarify methodological issues and to explain the concept of nature. Fiedler gives several reasons for this, three of which are as follows: (1) the medical art was a fairly well-developed art in the time of Aristotle and so had already addressed methodological questions; (2) the art possessed a scientific knowledge of its object but was also oriented toward production; and (3) the art was a clear instance of assisting nature in its own operations.

4 I do not believe that we currently have a reconstruction of Aristotle's account of the medical art that would enable us to properly understand the art's political consequences. The work of Anagnostopoulos $(2000 ; 2007)$ comes closest, and I agree with much of what he says. However, Anagnostopoulos actually discusses "ancient Greek views" on medicine, and frequently assimilates the thoughts of Plato and Aristotle (on which assimilation see footnotes 13 and 69 below). Moreover, Anagnostopoulos does not examine a number of issues that I believe are crucial for understanding the political consequences of Aristotle's account: e.g., the nature of health as a virtue of the body, the difference between health and happiness, and the relevance of pros hen predication for understanding the nature of mental health and medical care. As I proceed, I will also note some specific differences that exist between our interpretations.

5 However, I here note that a synoptic method is not unreasonable because Aristotle seems to have continually revised the majority of his treatises throughout his life; see especially Burnyeat (2001, 111-24) and (2004). I will also be circumspect when interpreting passages from those works (e.g., the Eudemian Ethics and Physics VII) that do not seem to be among the continually revised treatises, and I will not make any crucial use of passages from works of disputed authorship (e.g., Magna Moralia or Problems). 
to a higher expertise, especially political wisdom, which has happiness for its end (Section 4). The medical art is a productive expertise and so consists in a production-oriented understanding of the universal causes of health: this makes the doctor an expert on health, its production, and what is definitionally related to health (Sections 5 and 6). In virtue of being a rational power, the medical art can produce both health and disease; nevertheless, because of the art's metaphysical orientation to health, it produces health in accordance with its nature, and disease contrary to its nature (Section 7). The Aristotelian politician would understand that the medical art itself determines what can properly count as "medical care", and he would recognize that the art is in danger of being systematically distorted by those who would use the art for ends other than health. Consequently, the Aristotelian politician would see the need for something like the Hippocratic Oath (Section 8). I then explain how Aristotle's account of medicine supports the view that killing a patient is contrary to the medical art (Section 9), and I close by listing various reasons that an Aristotelian politician would have for protecting the inherent structure of medicine (Section 10). ${ }^{6}$

By way of preface, I here note that the ancient Greek word iatros (íxpós), though variously translated as "healer", “doctor”, or "physician”, is not simply ambiguous. Instead, there seems to have been, even in the time of Aristotle, a close semantic connection in iatros between "healer" and "medical doctor" since of course a medical doctor is someone skilled at healing. ${ }^{7}$ Something similar may be

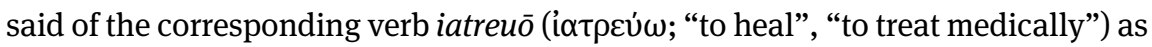

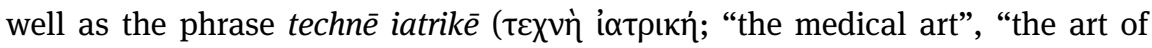
healing”). So while I will consistently translate iatros as "doctor" and (techne) iatrike as the "medical art," let us bear in mind that the former would have been heard as something like "expert healer," and the latter as something like the "the expertise of healing". These etymological facts no doubt had an influence on the

6 Here I should clarify that when I speak of an "Aristotelian politician” I am primarily thinking of the "true politician" ( $\mathrm{Pol}$ IV 1, 1288b27) who evaluates constitutions by reference to the best case (Pol IV 1, 1288b22; cf. I 5, 1254a36-9). However, I am willing to acknowledge that there may be some disagreement even among good politicians. This could occur either with regard to particular cases because no expertise "theorizes" about particular cases (Rhet I 2, 1356b30-2) or with regard to universal judgments-either because one can possess the virtues to different degrees (NE X 3, 1173a17-22) or because the expertise of political wisdom may not yet be perfected (cf. NE III 3, $1112 \mathrm{~b} 2-6)$.

7 At some point this may have been a case of "ancient semantic unity", on which see Barfield $(1973,81)$. Note, for example, how the Hippocratic Oath begins: "I swear by Apollo iētron." Should the word ietros (Ionic form of iatros) be translated "healer" or "physician"? Neither seems a perfect fit, though translators often opt for the latter, as e.g., Jones (1923, 299). On the other hand, there is no semantic connection between iatros and hugieia ("health"), and so it might be better to describe an iatros as a "curer" or "one skilled at curing". 
thoughts of ancient Greek speakers. By contrast, the English language derives its words relating to the medical art from other languages (e.g., "doctor" and "medicine” from Latin, "physician” from ancient Greek), and many English speakers do not know the origin of these words and so are not similarly guided by their etymologies. Consequently, though the phrase "physician-assisted suicide" may sound coherent to English speakers, the corresponding phrase in ancient Greek would probably have sounded strange and at least somewhat incoherent: "to kill oneself with the aid of an expert healer". ${ }^{8}$ As we will see, Aristotle would think that in this way ancient Greek speakers have a certain advantage: their language more correctly suggests the true account of the medical art.

\section{The End of the Medical Art is Health}

At the beginning of Aristotle's Nicomachean Ethics, we learn that the medical art, like every art (technē), has an end (I 1, 1094a1-9). Indeed, arts are distinguished from one another by their ends: for example, the end of the housebuilding-art is a house, the end of the horse-riding art is horse-riding, and similarly the end of the medical art is health (hugieia, I1, 1094a8). For some arts, the end is a proper activity (e.g., horse-riding), while for other arts, it is not the proper activity but a product beyond it (e.g., a house). In Eudemian Ethics II 1, Aristotle makes it clear that the end of the medical art is a product beyond the proper activity and not the activity itself-that is, the end is "health, not healing or curing" (1219a15-16). ${ }^{9}$

This is explained by a distinction that Aristotle draws between two types of activities: "incomplete" activities like healing and housebuilding, which are essentially means-to-ends, and "complete" activities like living or seeing, which are essentially ends. A locus classicus for this distinction is found in Metaphysics $\Theta$ 6, where Aristotle uses an example from medicine: slimming, i.e., making thin (ischnainein, 1048b19). ${ }^{10}$ While the slimming occurs, what is aimed at in the action

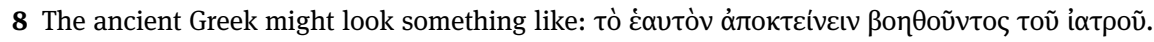
See Cooper $(1999,515-17)$ for a brief discussion of the language ancient Greeks used to describe suicide.

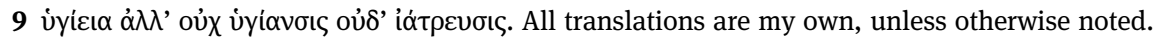
However, I have been influenced by existing translations, especially those found in Barnes (1995), Reeve (1998), Irwin (1999) and Reeve (2017), and I use the OCT editions of Aristotle's works, unless otherwise indicated.

10 For the use of ischnainō or cognates in medical contexts, see Physics II 3, $194 \mathrm{~b} 36$ as well as de Caelo II 12, 292b13-17, discussed below. The term is often used in the Hippocratic corpus. 
of slimming - the slimmed body-is not yet present. This gives slimming a "limit" (peras, 1048b18) because once the body has become slim, the action of slimming must stop. No further actions can count as slimming-since if one were to keep on doing the same things, one would not be slimming the body but emaciating it (cf. Prob 30.8). This is in contrast to an activity like seeing, which has no essential limit and need not stop for any internal reason (1048b26-7). ${ }^{11}$ Complete and incomplete activities have inherent teleological structures, and these structures cannot be changed by the will of an agent. ${ }^{12}$ Thus, healing is always an incomplete activity and so it cannot be the ultimate end of the medical art. Instead, the ultimate end must be health. ${ }^{13}$

But whose health? Aristotle makes it clear that the end of medicine is the health of the patient. In Politics III 6 when discussing the art of household management, Aristotle says that it is "essentially [kath' hauto] for the sake of the ruled, as we see in the other arts, e.g., the medical art and the gymnastic art. Yet incidentally [kata sumbebēkos] it may also be for the sake of the rulers-for nothing prevents the gymnastics trainer from sometimes being himself one of those who are being trained" (1278b38-9a3). There is, then, a certain disinterestedness to the medical art: it exists for the sake of the patient-in particular, the

11 Aristotle also says that, while it is true that at any moment in the activity of seeing, "one has seen" (1048b23), it is not true that at any moment in the activity of healing, "one has healed" (hugiastai; 1048b25). Following Burnyeat (2008) and others, I understand Aristotle to be using a linguistic point (progressive aspect implies perfected aspect) to indicate an underlying metaphysical structure.

12 See e.g., Makin (2006, 141-50) and Beere (2009, 221-30). Burnyeat (2008) argues that the passage from Metaphysics $\Theta 6$ comes from an ethical treatise, and that the distinction there articulated is not generally applicable to the rest of Aristotle's philosophy, especially his natural philosophy. However, we are considering of medicine largely from an ethical perspective, and the distinction in question does seem to explain why the end of the medical art is health, not healing (cf. NE I 1, 1094a3-6). See also Anagnostopoulos (2017) and Gonzalez (2019), who question Burnyeat's (2008) thesis in various ways.

13 By contrast, Anagnostopoulos $(2000,267)$ assumes that for both Plato and Aristotle, "the activities of restoring, improving, or maintaining health constitute the function, end, or goal of medicine" (my emphasis). Here two points are worth making. First, the activity of healing may be called an end of the medical art, but it is not the end of the medical art. This is because the end of each thing, qua that thing, is the ultimate end for the sake of which it exists (EE II 1, 1219a10-11), and it is clear that the ultimate end of medicine is the patient's health, which is (as yet) only imperfectly realized by the incomplete activity of healing. Second, Plato does not seem to possess the distinction between incomplete and complete activities, on which see Beere (2009, 14-17), and so it does not seem that Plato could have clearly given Aristotle's explanation for why the end of medicine is health and not healing, on which see also Baker (2015, 242-3). 
patient's health. ${ }^{14}$ Nevertheless, just as the gymnastics trainer may train himself, so too "someone who is a doctor might come to be the cause of health to himself. Yet he does not possess the medical art on account of being healed. But it just so happened [sumbebēken] that the same person was the doctor and the one healed" (Phys II 1, 192b24-26).

Insofar as health is the end of the medical art, it is also the "good" of the medical art-i.e., the good that the medical art accomplishes. Indeed, "in all sciences and arts the end is a good" ( $\mathrm{Pol}$ III 12, 1282b14-15) ${ }^{15}$ The reason for this is that to be a good is to have the nature of an end (NE I 1, 1094a2-3), and thus Aristotle sometimes speaks of "the good, i.e., that for the sake of which" (Meta A $2,982 \mathrm{~b} 10){ }^{16}$ Just as victory is the end $(N E \mathrm{I} 1,1094 \mathrm{a} 9)$ and good (NE I 7, 1097a19-20) of the general's art, so too health is the end (NE I 1, 1094a8) and good (NE I 7, 1097a19) of the medical art. ${ }^{17}$ Aristotle thinks that "no one demonstrates that health is a good, unless he is a sophist and not a doctor" (EE I 8, 1218b22-3); instead, everyone already agrees that health is a good ( $E E$ I 8, 1218a21-2), and this would seem to be the kind of knowledge that one naturally acquires when living a human life. ${ }^{18}$ And though the medical art is a cause of health being produced, "it is not the cause of health being good" (EE I 8, 1218b20-2; cf. NE VI 13, 1145a6-9). Instead, the end is always the cause of the goodness of what exists for the sake of

14 Compare the remarks of Socrates at Republic I, 341c-342e. When Aristotle in Politics III 6 says that the medical art exists for the sake of [charin] the patient, it is clear that he is indicating the beneficiary of the art, and not its goal or purpose, which would instead be health. This passage would thus seem to align with the common interpretation of the dual use of hou heneka ("that for the sake of which")-to men hou or to de hoii (e.g., DA II 4, 415b2-3)-which has been taken to indicate the goal for which and the beneficiary for whom. See e.g., Kullmann (1985, 171-2) or Sedley (1991, 180). However, see also Gelber (2018), who questions the common interpretation, but does not discuss the passage in question.

15 See also Magna Moralia I 1, 1182a34-35 and Nicomachean Ethics I 1, 1094a1-2. We explain the metaphysical reason for this in section 7 . Here I should also note that passages such as these also make it clear that Aristotle, just like other ancient Greeks, used the term hugieia ("health") to signify what we would call "good health".

16 See e.g., Baker (2017, 1840-1).

17 See also Eudemian Ethics II 10, 1227a18-31, discussed in part below. By way of contrast, Barney $(2008,311)$ and others, while interpreting a difficult sentence in Aristotle's ergon argument (NE I 7 , 1097b25-8), have maintained that the good of the every craftsman is actually performing his proper activity well-in which case the good of the doctor would be "healing well", not the health of the patient. However, see Baker (2015) in which I argue against Barney on this point.

18 According to Posterior Analytics I 2, the sophist gives explanations from incidental causes (71b10). Thus, a sophist might argue as follows: "Health produces pleasure; what produces pleasure is good; therefore, health is good.” 
that end (EE I 8, 1218b16-18; NE I 1-2), and so health is the cause of the medical art being something good. ${ }^{19}$

\section{The Nature of Health ${ }^{20}$}

Health is a "virtue [aretē] of the body" (Rhet I 5, 1361b3; Phys VII 3, 246b3-4). Aristotle here uses the word "body" (sōma) to indicate a living body (cf. Sens 1, 436a18-19), which is "a natural instrumental [organikon] body" informed by a soul (psychē) (DA II 1, 412b5-6). Such a body possesses organa - "instruments" or "organs"-which the soul uses to perform various operations. ${ }^{21}$ Though Aristotle famously maintains that the soul and body are one as the wax and the seal (i.e., the matter and the form) are one (DA II 1), he also thinks that the soul is the principle of life and of various life-activities (DA II 2). ${ }^{22}$ Consequently, so long as the soul persists, it somehow retains its powers of activity even when it cannot exercise them due to a defect in the bodily organ: "if an old man should receive the eye of a young man, he would see as the young man. Thus, old age is not due to the soul being somehow affected but to that in which the soul resides [i.e., the body] being somehow affected, as is the case with drunkenness and disease" (DA I 4, 408b21-4). Thus, health would seem to be a virtue of a body in the sense that it is a state that disposes a living, instrumental body for unimpeded use by the soul.

Aristotle seems to assume this sort of view in Metaphysics $\Delta 20$ where we read that "state" (hexis) may indicate "a disposition [diathesis] according to which thatwhich-is-disposed is disposed well or poorly, either in itself [kath' hauto] or in relation to something else [pros allo], for example, health is a certain state [hexis tis]

19 On ends as sources of value for what leads to them, see Lear (2009). On the medical art as a good sort of thing, see Metaphysics $\Delta$ 16, 1021b14-20, which I discuss in Baker (2017, 1842-4).

20 In this section and the next, I give a sketch of Aristotle's account of health that emphasizes health's metaphysical structure and its relation to the human good. For treatments of Aristotle's account of health that focus on its historical context and health's biological underpinnings, see e.g., Lloyd (2003, 176-201) and van der Eijk (2017, 226-33); for a treatment that relates health to Aristotle's doctrine of the mean, see Tracy (1969, 157-97).

21 See Menn (2002) who both endorses the translation of organikon (DA II 1, 412b6) as "instrumental" and emphasizes that the soul uses the entire body as an instrument. See also Frey (2007), who argues that in order to be a bodily organ, it is not sufficient to perform the proper work of a bodily organ, as an artificial organ might do.

22 See especially Frey (2015), who argues that the soul should be understood primarily a principle of life and only secondarily a system of capacities. 
for it is a disposition of this sort" $(1022 \mathrm{~b} 10-12) .{ }^{23}$ The body seems to be healthy when it is disposed well "in itself", and this occurs when the matter of the body is disposed well with respect to the body's form. More specifically, the body is healthy when the "the moist and the dry and the hot and the cold and generally those things from which the animal is first composed" (Top III 1, 116b18-20; cf. Phys VII 3, 246b4-6) are disposed well with respect to the soul that informs the body. ${ }^{24}$

Nevertheless, the body also seems to be healthy when it is disposed well "in relation to something else". This is so because, as we noted above, the soul is not only the form of the body but also the principle of life-activities. ${ }^{25}$ Here we should note that each power of the soul has an ergon or proper work, and an ergon of an $\mathrm{X}$ is the end for the sake of which an X, as an X, exists (EE II 1, 1219a6-11)-for example, seeing is the ergon of the power of vision ( $E E$ II 1, 1219a16). Yet because the power of vision is the form of the eye (DA II 1, 412b18-3a2) seeing is also the ergon of the eye as a whole (cf. HA X 1, 633b18-22). Thus, the eye is healthy when it is disposed well not only in itself but also in relation to "something else"-namely, seeing, which is the ergon of the eye. ${ }^{26}$ And so Aristotle seems to be speaking of the health of the eye when he says, "The virtue of the eye makes the eye and its work [ergon] good-for we see well by means of the virtue of the eye" (NE II 6, 1106a1719). ${ }^{27}$

The whole body is also prior by nature to its parts, and all the parts exist for the sake of the whole (PA I 5, 645b14-20; Pol I 2, 1253a18-25; Meta Z, 1035b9-14). Consequently, the primary case of health seems to be that of the whole body, and so "one who is going to treat the eyes must also know about the whole body" (NE I

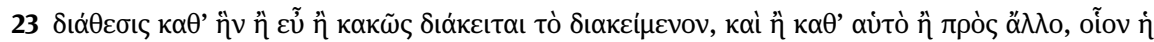

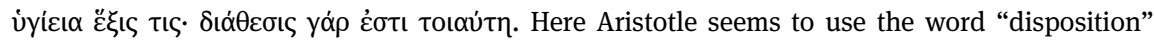
(diathesis) for the genus under which "state" (hexis) falls (cf. Meta $\Delta 19,1022 \mathrm{~b} 1-3)$, and thus he identifies health both as a state and as a kind of disposition. However, in Categories 8 he uses the term "disposition" (diathesis) to signify an imperfect state (hexis), one that is easy to change. There he says that health is a disposition and not a state since health can be easily changed (8b35-9a1), but he also acknowledges that health and disease may become so stable that they could be considered states (9a1-4). See also the first comment in footnote 44.

24 There are other virtues of the body besides health, but these are found "in what is posterior, for strength is found in sinews and bones, and beauty seems to be a certain symmetry of the members" (Top III 1, 116b20-2).

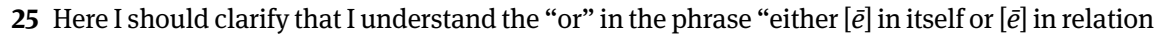
to something else" (Meta $\Delta 20$ 1022b10-11) to be an "inclusive or".

26 See also Tracy $(1969,162-3)$, who argues that it is Aristotle's considered view that health is not identical to the "balance of the hot and the cold" but is rather a state that supervenes upon that balance (cf. Top VI 6, 145a33-b11, and APo I 13, 78b18-20).

27 Note that Aristotle thinks that something can possess a virtue even when not active (NE I 8, 1098b30-9a7) and so he does not consider health to be a certain activity of the body. 
13, 1102a19-20). Nevertheless, the body is composed of its parts, and it seems that one can make a correct judgment about the health of the whole body, only if one has adequate knowledge of the parts: "no one is healthy in his whole body but not in any part. All the parts, or most of them and the most critical, must have the same condition as the whole" (EE VIII 3, 1248b14-16).

Health, being a virtue of the body, is also "a certain perfection [teleiōsis tis]" of the body (Meta $\Delta$ 16, 1021b20-1; Phys VII 3, 246a13). Each thing is ordered to its proper perfection, ${ }^{28}$ and so "the body aims at health" just as each thing "aims at its own proper good" (EE I 8, 1218a31-2). Because the body is by nature inclined toward health as to an end, the medical art can in turn take its end from that of the body (see Section 5.4). When the doctor advises a patient to walk after dinner, he recommends an activity that will aid the body in its own operation of digesting (cf. APo II 11, 94b8-21). By observing how the body can spontaneously achieve the end of health, the doctor can improve his own art. ${ }^{29}$ Quite generally, "art [techne] completes what nature cannot accomplish, and in other cases imitates nature" (Phys II 8, 199a15-17). ${ }^{30}$

Disease (nosos) is the contrary of health. Since contraries (enantia) are in the same genus, disease is also a state (hexis) of the body, but it is a state by which the body is "disposed badly" either "in itself" or "towards something else" (cf. Meta $\Delta$ $20,1022 \mathrm{~b} 11-12)$. As such, it is not a virtue and perfection of the body, but a vice and corruption of it (Phys VII 3, 246a10-17). Aristotle thinks that all contraries are related to one another as positive form to privation, and thus health is the positive form and disease is the privation of health. ${ }^{31}$ The word "privation" (sterēsis) is said in many ways, but the one relevant for the case of disease seems to be the one that is applied when "something that is naturally such as to have [a property] does not have it” (Meta $\Theta 1,1046 a 32-33)$. Thus, even though a rock is not healthy, it is not thereby diseased because it is not naturally such as to be healthy. Instead, it is the living body that can be diseased precisely because it is naturally such as to be healthy (cf. Sens 1, 436a18-19); thus, disease, as a privation of health, is "contrary

28 See Leunissen (2015), who discusses the notion of perfection in Physics VII 3.

29 See Johansen $(2017,129)$. On health occurring spontaneously, see Parts of Animals I 640a28-9 and Metaphysics Z 7, 1032b21-6.

30 See also Politics VII 17, 1337a1-3 and Protrepticus B13, following the numbering of Düring (1961). Two clarifications are also here worth making. First, I assume that it is only sometimes that nature cannot accomplish health. If nature never accomplished health, the natural philosopher could not properly study health, on which see section 5.4. Second, even though Aristotle thinks that the medical art, just like all arts, came to be in order to fill certain needs of human nature, such an origin does not fully explain the inherent teleology of the art, on which see section 7 .

31 See Metaphysics $\Lambda$ 5, 1071a9-10; Z 7, 1032b2-5 as well as $\Theta 2$, 1046b4-15, discussed below. 
to nature" (Meta H 5, 1044b29-5a6). As we will later see, the natures of health and disease largely determine the inherent orientation of the medical art (Section 7).

\section{Health is to Medicine as Happiness is to Practical Wisdom}

Even though health is a good (EE I 8, 1218b22-3), it is distinct from the best good achievable by humans, which Aristotle labels "the human good" (NE I 2, 1094b7), and people generally call "happiness" (eudaimonia, NE I 7, 1097b22-3). ${ }^{32}$ The best good is most of all an end: it is desired for its own sake and not for the sake of something else, and it is that for which everything else is to be chosen ( $N E$ I 2, 1094a18-22). By aiming at this best and highest good, an individual should organize his life and the politician should organize his state (NE I 2, 1094a22-b10). Because health is productive of pleasure and life, it is often thought to be the best good (Rhet I 6, 1362b15-16; cf. NE I 8, 1099a27-8), especially by those who are sick (NE I 4, 1095a24). ${ }^{33}$ However, Aristotle identifies the best good as a certain "activity of [the rational part of] the soul on the basis of virtue" (NE I 7, 1098a16-17). ${ }^{34}$ This is an objective and properly human achievement (NE I 7, 1097b33-a4), though it does necessarily involve pleasure (NE I 8, 1099a7-21).

Health is no part of this best good: the virtue spoken of in the definition of happiness is properly "human virtue", and this is "not virtue of the body but virtue of the soul" (NE I 13, 1102a16-17). ${ }^{35}$ Nevertheless, some degree of health is a necessary precondition for happiness (NE I 9, 1099b27-8; EE I 2, 1214b15-17): "No activity is perfect when impeded, and happiness is something perfect. For this reason, the happy person needs the goods of the body" (NE VII 13, 1153b16-18). For example, in order to engage in many practically virtuous activities, e.g., standing

32 "Happiness" is certainly an imperfect translation for eudaimonia, which is not a feeling but an activity, but it is defensible translation, on which see Kraut (1979).

33 See Jouanna (1999, 323-4), who gives evidence that ancient Greek doctors themselves often did not challenge that popular opinion that health was the best good.

34 Aristotle famously adds "and if there are more virtues than one, on the basis of the best and most teleion and moreover in a teleion life" (NE I 7, 1098a17-18). The vexed question of how to interpret these lines falls outside the scope of this paper.

35 According to some scholars, Aristotle thinks that eudaimonia is composed of many or all noninstrumental goods, including health. The view finds early expression in Ackrill (1980). However, see Heinaman (2007) who persuasively argues that Aristotle always understands eudaimonia to be a certain activity of the rational part of the soul. When Aristotle suggests in Rhetoric I 5 that we can consider health to be part of happiness, he would seem to be noting a view that one can assume for the purpose of persuasion. 
firm in battle or contemplating philosophical truth, "we need a healthy body" ( $N E$ $\mathrm{X} 8,1178 \mathrm{~b} 34-35)$. Thus, we should desire health (NE III 1, 1111a31), and we should desire it for the sake of goods of the soul (Pol VII 1, 1323a38-b21), and above all for the sake of the best good (NE I 2, 1094a27-b7). These goods of the soul are much more valuable than health, and consequently, even when the virtuous person is suffering from sickness or other misfortunes and thus cannot achieve happiness, "what is beautiful and noble shines through" (NE I 10, 1100b30-1; Pol VII 13, 1332a19-21).

Now Aristotle emphasizes that higher ends limit the pursuit of lower ends ( $N E$ I, 1-2), and thus health, as an intermediate end, both limits and is limited. In Politics I 9, he writes,

the medical art is for [the sake of] health in an unlimited way, and each of the arts is for [the sake of] its end in an unlimited way-for they wish to accomplish the end most of all-but each is not for [the sake of] the means in an unlimited way, because the end is a limit in all the arts $\ldots(1257 \mathrm{~b} 25-8)^{36}$

At the end of this passage, we read that the medical art does not pursue the means to health in an unlimited way: the medical art directs one to give drugs and perform procedures only insofar as these things promote health. Health here serves as a limit on the use of the things that promote health (cf. Meta $\Theta 6,1048 \mathrm{~b} 18-35$, discussed in Section 2). Nevertheless, at the beginning of this passage, Aristotle makes it clear that the medical art, like any other art, pursues its end in an unlimited way. ${ }^{37}$ An art's pursuit of its end may of course be limited, but it is not limited by anything internal to art itself. This limitation can occur in various waysfor example, because there is a defect in the matter that the art must work on (cf. Section 6), or because the art is subordinated to a higher art, which aims at a higher end. The medical art's pursuit of health will be especially limited by its subordination to practical wisdom (phronēsis) and political wisdom (politikē), both of which aim at the best good (NE I 1-2; Pol I 1, 1252a1-7; cf. Pol I 10, 1258a27-34). ${ }^{38}$

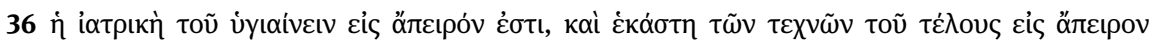

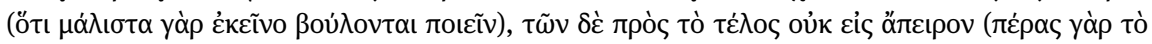

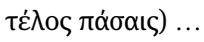

37 Cf. Protrepticus B71, where Aristotle assumes that when one aims at health as an end, one thereby aims at the greatest degree of health, ceteris paribus.

38 As Aristotle explains in Nicomachean Ethics VI 8, "Prudence (phronēsis) and political wisdom (politike ) are the same state, yet their being is not the same" (1141b23-4). Both states say what should be done, the former with respect to the individual and the latter with respect to the common good of the polis. Here I use politike as a "common term" for both the state that legislates and the state that makes decrees about particulars (1141b26). There are also other kinds of practical wisdom (1141b30-3). 
Some examples may illustrate the sort of limitation that occurs by subordination. First, if any public doctor should zealously advise his patients not to become soldiers or philosophers because philosophizing and soldiering can be detrimental to health (cf. NE VII 12, 1153a20; IX 8, 1169a18-b2), the politically wise person will have grounds to regulate this doctor's recommendations precisely because political wisdom has for its end a higher good than health. Second, if a doctor should refrain from treating a patient because that patient does not wish to be healed, it would not be the medical art that tells the doctor to refrain. It would instead be the doctor's practical wisdom (or some participation thereof) that leads him to judge that, e.g., since some goods are greater than health, a patient may have good reasons for refusing treatment (cf. Pol IV, 1288b10-21, discussed in Section 6). In fact, third, Aristotle suggests that health, though good in itself, may not be good for someone precisely because he will eat anything whatsoever in order to attain it ( $N E \mathrm{X} 3,1173 \mathrm{~b} 25-8)$. Here Aristotle is perhaps thinking that it is better to sacrifice one's health than to eat some things-for example, human flesh (cf. NE VII 5, 1148b19-27). The politician may prohibit eating some foods, even if those foods are beneficial to health, and the doctor may consequently refrain from prescribing those foods. Yet the medical art itself still aims at health in an unlimited way, even though considerations coming from a higher expertise limit that aim.

\section{The Medical Art as a Rational Expertise}

What sort of expertise does the medical art consist in? To answer this, we should first note that, according to Aristotle, "all thought is either practical, productive or theoretical" (Meta E 1, 1025b25). The end of theoretical thought is universal "truth" (alettheia, NE VI 2, 1139a27-29; Meta $\alpha$ 1, 993b20-1) which is to say, "truly cognizing what is" (Protrep B65). The end of practical thought is a particular "action" (praxis, $N E$ I 3, 1095a5-6), by which Aristotle seems to mean a reason-involving activity that remains within the agent and whose starting point is a choice (prohairesis) with a view to the highest end (NE VI 2, 1139b1-4). ${ }^{39}$ The end of productive thought is either a particular product (e.g., health, a house, or a ship) or a particular activity that uses external matter (e.g., a performance on the harp). ${ }^{40}$ Because productive thought, as such, is not for the sake of the highest end but for some lower end, productive thought is subordinated to practical thought (NE VI 2, 1139b1-3),

39 Aristotle also says that the ergon of practical thought is practical truth (NE VI 2, 1139a26-7), but a discussion of Aristotle's notion of practical truth falls outside the scope of this paper.

40 See Aquinas (1969, 6 [1, 1, lines 189-210]). 
though it is not a subset of practical thought (NE VI 4, 1140a5-6). ${ }^{41}$ Art (technē) is defined as "a productive state involving a true account [logos]" (NE VI 4, 1140a10), ${ }^{42}$ and with one change one might reasonably propose an Aristotelian definition of the medical art as "a state productive of health involving a true account." ${ }^{43}$ I will discuss each element of this proposed definition in turn.

\subsection{A State ...}

When Aristotle says that art is a "state" (hexis, NE VI 4, 1140a10), he seems to use the word "state" as he does in Categories 8: "A state [hexis] differs from a disposition [diathesis] in being more stable and longer lasting. Such are the expertises [epistèmai] and the virtues. For expertise seems to be one of the things that are permanent and hard to change" $(8 \mathrm{~b} 27-30) .{ }^{44}$ Consequently, when the medical art is fully acquired, it is a state and thus hard to change. The trainee doctor, however, does not yet possess the medical art as a state since "those who do not completely possess an expertise but are easily changeable are not said to have a state [hexin], although they are disposed [diakeintai] towards the expertise in a better or worse way" (9a5-8). In order to acquire the medical art as the state that it is, one will need to perform activities characteristic of the medical art repeatedly and under the

41 For a discussion of the way in which practical thought is distinguished from productive thought by being specially joined to desire, see Anscombe (1965).

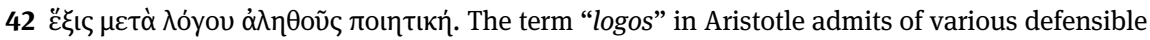
translations including "reason". I have here translated "logos" as "account", but I recognize that this is not a perfect translation because "logos" and "account" have very different semantic ranges. For discussion of the term in Aristotle, see Makin (2006, 37-39), Moss (2014, 203-28), and Johansen (2017, 101n.8).

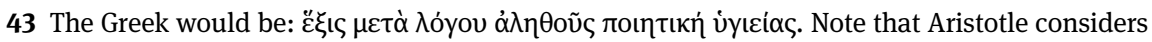
the art of gymnastics to aim not at health per se but at bodily "fitness" (euexia; EE I 8, 1218a36), even though fitness seems to imply health (Top II 8, 113b35).

44 Two comments are here in order. First, in this passage Aristotle seems to be using the word "state" (hexis) slightly differently than he does at Metaphysics $\Delta 20,1022 \mathrm{~b} 10-14$, where it seems that states can be stable or unstable. However, one might try to reconcile the passages by saying that perfect states are stable whereas imperfect states are unstable. Thus, at Categories 8, 8b27-30 Aristotle is discussing perfect states, but at $\Delta 20,1022 \mathrm{~b} 10-14$ he is discussing states that can be either perfect or imperfect. Second, here and elsewhere, I will translate epistēmē by "expertise". I do so because I will often be focusing on those contexts in which Aristotle uses the word epistēme to cover both theoretical and practical/productive bodies of knowledge. For example, Aristotle speaks of technai as "productive epistēmai" at Metaphysics $\Theta 2,1046 \mathrm{~b} 2$, discussed below. Aristotle distinguishes strict and less strict uses of the word epistēmē at Nicomachean Ethics VI 3, 1139b1819, and I take myself to be attending to the less strict use, on which, see Lorenz $(2014,246)$ and Baker (2015, 263n.74). 
guidance of a teacher (NE II 1, 1103a31-4, b12-13): "States come about from similar activities" (NE II 1, 1103b21-2). ${ }^{45}$

\subsection{A State ... Involving a True Account}

The medical art is also a state "involving a true account [logos]" (NE VI 4, 1140a10). ${ }^{46}$ Art is a perfection of the rational part of the soul on the basis of which it makes true judgments (NE VI 3, 1139b15-17), but these judgments must also be made in light of correct explanations or accounts. In Metaphysics A 1 Aristotle explains that the man who knows the medical art possesses a rational account and is thus distinguished from the man with mere experience, whose ability to heal is based on memory and perception. The man with mere experience may somewhat consistently identify "this very disease" (tèndi tèn noson, 981a11) and he may use a name for it (e.g., "ophthalmia”), but his grasp of the disease is essentially based on perception and memory, whose objects are particulars (e.g., this very redness and inflammation). Consequently, his experience is also essentially "of particulars" (981a15-16). By contrast, the man with art uses his intellect to grasp "the cause" (981a28), where this involves some understanding of how symptoms manifest conditions in different sorts of bodies (e.g., "the phlegmatic or bilious") and how different treatments affect these conditions (981a10-12). Unlike the man of experience, he can both explain "why" the symptoms occur and "why" different medications will help people with different sorts of bodies (981a29). Consequently, the medical art, and art generally, is essentially “of universals” (981a16), and not of particulars as such. ${ }^{47}$

\subsection{A State Productive of Health Involving a True Account}

Nevertheless, the medical art is also a productive state, and what is produced is always something particular (981a16-17): a doctor "does not heal human

45 Cf. Metaphysics $\Theta 8,1049 \mathrm{~b} 30-50 \mathrm{a} 2$ and de Memoria 2, 452a27-30. It is also worth noting that because the medical art is a state of the rational part of the soul, many of these repeated activities will need to be intellectual.

46 In rest of Section 5 and in the first part of Section 7, I agree with much that is said by Johansen (2017), but see also footnotes 49, 54 and 74, where I also question parts of his interpretation.

47 See also Nicomachean Ethics II 2, 1104a2-10, Rhetoric I 2, 1356b30-3 and Posterior Analytics II $13,97 \mathrm{~b} 25-7$. Here it is worth clarifying that the man with mere experience may grasp what is general and even logically universal. However, until he grasps that the $\mathrm{X}$ is $\mathrm{Y}$ because of $\mathrm{X}$ itself and as X, he does not grasp the universal, as Aristotle understands it (cf. APo I 4, 73b26-32). See e.g., Hasper and Yurdin (2014, 130-3), Gasser-Wingate (2016, 17-18) and Johansen (2017, 133). 
being except incidentally, but Callias or Socrates" (981a18-19; cf. NE I 6, 1097a11-13). In order to heal a particular human being, e.g., Callias or Socrates, the doctor will need to see the particular as included in the universal, and this will require experience. If he grasps the universal without sufficient experience, he will often be less successful at healing than the man with experience alone (Meta A 1, 981a20-4). ${ }^{48}$ Thus, even though the medical art is a rational expertise and so proceeds from knowledge of the universal, it is also a productive expertise and so terminates in experience and perception of the particular. ${ }^{49}$

Indeed, Aristotle in NE X 9 says that the man who grasps both the universal and the particular will actually be able to give better treatment than the man with mere experience, who grasps the particular alone. "This is because expertises (gar hai epistèmai) are of what is common [to many cases]" (1180b15-16), and as we explained earlier, this means that expertises enable one to give universal explanations. Aristotle concedes that someone with mere experience may treat an individual patient well, but he suggests such a person will be effective only in a limited range of cases. The doctor is effective in a wider range of cases precisely because he grasps the universal. ${ }^{50}$

48 Grasping the universal without experience seems to be possible because one can acquire the medical "universals" from a teacher, on which see e.g., Cambiano (2012, 21-2).

49 This requirement seems to result in (at least) three interpretative options. First, experience is a mere necessary precondition for possession of the medical art, which wholly consists in a grasp of the universal; cf. Müller $(2018,152)$ : "since knowledge that constitutes craft is universal, it is more like theōria than praxis." Second, the medical art is a kind of experience that is differentiated by a grasp of the universal; cf. Johansen $(2017,113)$ : "craft is a certain kind of experience, the one characterised by a logos." Third, the medical art consists partly in a grasp of the universal, but partly in experience; cf. Beere $(2009,72)$ : "[s]ome powers seem to be hybrids, which consist only partly in rational comprehension." Some version of this third option seems to me the most plausible, though perhaps we should add that the medical art consists primarily in a grasp of the universal. The first option does not seem to account for the fact that the medical art is essentially productive. The second option seems to misidentify the genus of art, which is a state of that part of the soul which is rational in itself (cf. $N E$ VI 3, 1139b15-17), whereas experience is a condition not of this part but of the internal sense powers.

50 See Moss $(2014,226)$ and Johansen (2017, 130-2). Thus, while Aristotle's emphasis on experience does seem to align him with the Empiricist doctors in the Hellenistic period, his claim that experience when joined with an explanatory universal is even more productive would also put him in opposition to them. Consequently, Nicomachean Ethics X 9, 1080b7-24 as well as de Repiratione 27(21), 480b22-30 (discussed below) seem highly problematic for the "empiricist" interpretation of Aristotle's practical epistemology that has been offered by Lorenz and Morison (2019). 


\title{
5.4 A State Productive of Health Involving a True Account
}

There is also a way in which the medical art shares some of its content with natural philosophy, and this occurs because health can occur both by nature and by art. Consider the closing lines of Aristotle's Parva Naturalia:

\begin{abstract}
It belongs not only to the doctor but also to the natural philosopher to say the causes of health and disease, at least up to a point. It should not escape our notice how these disciplines differ and the way in which they consider different subject matter-for normal practice is evidence that the disciplines are coterminous up to a point: subtle and inquisitive doctors refer to natural science and judge it right to derive their principles from it, while the most cultivated of those working at the philosophy of nature generally conclude [their treatises] with [the articulation of] medical principles [archās]. (de Respiratione 27(21), 480b22-30; cf. Sens 1, 436a17-b1 $)^{51}$
\end{abstract}

Natural philosophy and the medical art both consider health but for different purposes and in different ways. Natural philosophy is a theoretical expertise that ultimately aims at contemplating the universal truth concerning those things that occur by nature. Health is a naturally occurring perfection the living body (Section 3), and so natural philosophy likewise aims at contemplating the universal truth concerning health. By contrast, the medical art is a productive expertise that ultimately aims at producing particular instances of health in particular patients. The medical art is a rational expertise and so does consider the universal nature of health, but it does so with the ultimate goal of producing particular instances of health (Section 5.3) and consequently it need not always pursue the same level of accuracy about the universal that natural philosophy does (cf. NE I 7, 1098a29-32).

Nevertheless, Aristotle observes that "subtle [kompsoi] and inquisitive doctors" (480b27) take their principles from natural philosophy, and he clearly thinks that they are right to do so (cf. Protrep B46 and NE I 13, 1102a21-3). In Meta A 1, Aristotle implies that such doctors are the "principal artificers" (architekones) of the medical art and consequently most suited to teach it (981a30-b10). ${ }^{52}$ And at the beginning of the Parva Naturalia, Aristotle says that such doctors "pursue their art in a more philosophical way" (Sens 1, 436a20-b1) than those who do not so derive their principles. But why is it proper for the medical art to derive its principles from natural philosophy and not vice versa? The key reason seems to be that health is

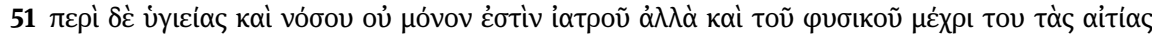

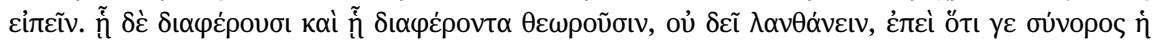

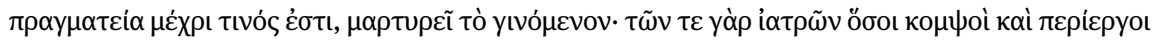

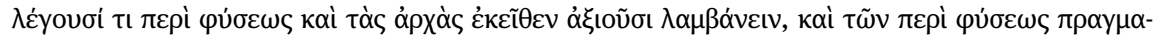

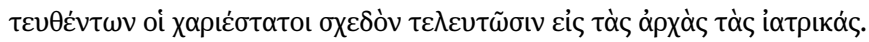

52 Cf. van der Eijk $(1995,451)$. 
something that can occur by nature (cf. PA I 1, 640a28-9; Meta Z 7, 1032b21-6; NE VI 12, 1144a4). Consequently, it is proper to natural philosophy to consider the universal truth about health because it is proper to natural philosophy to consider the universal truth about those things that occur by nature (cf. Meta E 1, 1025b1921). By contrast, the medical art considers health insofar as it is achievable by art (cf. NE VI 4, 1140a14-16; Meta E 1, 1025b22). Nevertheless, it is proper for the medical art to derive its universal principles from natural philosophy because the medical art does not produce health by itself but only by assisting and imitating nature (cf. Phys II 8, 199a15-17, discussed in Section 3). ${ }^{53}$ In this way, the medical art is dependent on natural philosophy but not vice versa; consequently, the medical art should never make claims about health that disagree with those of natural philosophy. ${ }^{54}$

\section{The Scope of Medical Expertise}

Given what we have said so far, we can already discern a certain scope and limitation to the medical art. For example, because the doctor understands bodily health with a view to production (Section 5), he must grasp both the nature of health and the means to it: "Doctors sometimes do not judge well what the healthy

53 I take this to be more or less the view that is articulated by Aquinas (1985, 9 [prohemium, lines 306-21]), when he comments on Sense and Sensibilia I, 436a17-b1. There is one clear advantage to this sort of interpretation: it gives an explanation for why it is only some arts that derive their universal first principles from natural philosophy. For if the end of an art does not occur by nature, that art will not properly derive its universal first principles from natural philosophy. For example, the boat-building art does not derive its first principles from natural philosophy because boats do not occur by nature. Nevertheless, the boat-builder might still make use of truths from natural philosophy insofar as e.g., the materials of a boat do occur by nature. Somewhat similarly, a subtle and wise doctor might make use of truths from geometry in order to explain medical facts (cf. APo I 13, 79a10-16), even though the medical art does not derive its first principles from geometry.

54 Four comments are here in order. First, I take it that medicine always properly derives its first principles from natural philosophy and not just “sometimes”, pace Johansen $(2017,124)$. Second, even though medicine properly derives its principles from natural philosophy, someone who does not possess a sophisticated knowledge of medicine can still count as a doctor: this is especially clear from Politics III 11, 1282a1-5, discussed in section 8. Nevertheless, these less wise doctors should defer to the wiser doctors, who do derive their principles from natural philosophy (cf. Meta A 1, 982a17-19). Third, Aristotle thinks that no art considers particular cases as such (NE II 2, 1104a5-10; Rhet I 2, 1356b30-2), and so it seems that he would allow for the possibility that good doctors could disagree with one another with regard to particular cases. Fourth, Aristotle implies that there is need of deliberation in medicine because the medical art has not yet been fully worked out (NE III 3, 1112b2-6), and so Aristotle might have allowed for the possibility that good doctors could disagree with one another even about certain universal medical judgements. 
body consists in, and sometimes they do not attain what would produce the aim laid down for them; but in the arts and expertises one should have within one's control both the end and the actions directed to this end" (Pol VII 13, 1331b34-8). This will require the doctor to understand the causal powers of many other things, e.g., various foods or drugs, yet he understands all of them in relation to the production of health (NE V 9, 1137a12-17). And even though the doctor is an expert on the patient's health, he is not an expert on what is overall good for the patient (Section 4). This is important to note because sometimes the healthier condition is not always better overall for the patient: for example, the medical art "says that pleurisy is a worse disease than a tendency to stumble, and yet the latter may be worse incidentally [kata sumbebèkos], if the stumbling man should on account of falling happen [sumbaiē] to be captured or killed by his enemies" (NE V 11, 1138b2-5).

What then determines the proper scope of medical expertise? Aristotle suggests an answer to this question in Metaphysics $\Gamma 2$ where he explains that some things are called "healthy" insofar as they are definitionally related to the primary case of health: "one thing as preserving health, another as producing it, another as being a sign of health, another as being receptive of it" (1003a35-b1). This is known as pros hen ("related to one") predication. ${ }^{55}$ Food is called "healthy" insofar as it produces health in the body, complexion and urine insofar as they are signs of health (cf. Meteor IV 2, 380a1-2), and bile and phlegm insofar as they are receptive of health (Phys II 1, 194a23-4). Because such "healthy" things are definitionally related to the primary case of health, which is that of the body, they do seem to fall under the scope of the medical art. ${ }^{56}$ By contrast, some things are called "healthy" only by an extension of the term, or "metaphorically." 57 For example, Aristotle says, "He who has opinions is, in comparison with the one who understands [ton

55 This kind of predication is also called "focal meaning”, or "core dependent homonymy". See also Eudemian Ethics VII 2, 1236a17-23, which articulates the requirement of asymmetrical account inclusion: $\mathrm{x}$ is the focal/core case for $\mathrm{y}$ only if the account of $\mathrm{x}$ is cited in the account of $\mathrm{y}$, but not vice versa. For further discussion, see Shields (1999) and Ward (2008).

56 In Metaphysics $\Gamma 2$ Aristotle makes this point shortly after noting that "healthy" and "being" are predicated pros hen: "And so just as there is one expertise [epistēmē] concerned with all healthy things, the same goes for other expertises. It not only belongs to one expertise to consider those things that have one common notion, but also those things that are related to one common nature; for even those in a way have one common notion" (1003b11-15; modified translation of W. D. Ross in Barnes [1995]). The "expertise that deals with all healthy things" would seem to be the medical art.

57 In various contexts (e.g., DA II 8, 420a29; III 3, 428a2; and Meta $\Delta$ 16, 1021b28-9) Aristotle speaks of things being spoken of kata metaphoran ("by extension"). Whether this phrase is appropriately translated as "metaphorically" is a question that falls outside the scope of this paper, but see the definition of metaphora ( $\mu \varepsilon \tau \alpha \varphi \circ \rho \alpha \dot{)}$ ) at Poetics 21, 1457b6-9. 
epistamenon], not in a healthy state [hugieinōs] in regard to the truth" (Meta $\Gamma 4$, 1008b30-1). Such a "healthy" condition is not definitionally related to the primary case of health, and so would not fall under the doctor's expertise.

Consequently, many things that we might designate with the term "mental health" would not fall under the medical art, as Aristotle conceives it; indeed, if we were to call moral virtue "mental health", such health would not fall under the medical art because it is not definitionally related to the primary case of health. Nevertheless, some things that we would call "mental health" or "mental illness" would fall under the medical art, and these would be those conditions of the soul that have some direct causal connection to the primary cases of health or disease. For example, it would properly fall to the doctor to treat those people who suffer from bad states of the soul that are "due to disease [nosos]" or to "having diseased conditions [nosemmatōdeis]": for example, "the slave who ate his fellow slave's liver" and those who "chew on coal and dirt" (NE VII 5, 1148b24-31). ${ }^{58}$ In such treatment, the doctor understands he is treating bodily organs so that they may be used in an unimpeded way by the soul (cf. EE I 3, 1214b28-34).

There are also degrees of bodily health (NE X 3, 1173a24-8), and the medical art concerns all of them, though not all equally. Consider Politics IV 1, which discusses the unity and comprehensiveness of art.

... it is proper to one <expertise > to consider what suits each kind of thing. For example, $<$ the gymnastics trainer considers> [1] what sorts of training benefit different sorts of bodies, [2] what sort is best (for the best training will necessarily suit the body that is best equipped by nature), [3] what single form of training benefits most people (for this too is a work of the gymnastics art); and [4] if a someone does not desire the best habit of body or the greatest athletic skill that he might attain, it is no less the office of the trainer or the gymnastics teacher to impart this [lesser] capacity as well. We see that this principle similarly holds in the medical

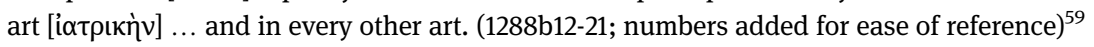

58 In such cases, the use of the terms "healthy" and "diseased" would be instances of pros hen predication, and not mere extensions of the term. A proper discussion of Aristotle on "mental health" must fall outside the scope of this paper. However, I will observe that discussions of Ahonen (2014, 69-102), Irwin (2013) and Harcourt (2013) do not address the relevant fact that, according to Aristotle, things can be called "healthy" in very different ways (properly, pros hen, by extension, etc.), and that only some of these healthy things fall under the expertise of medicine.

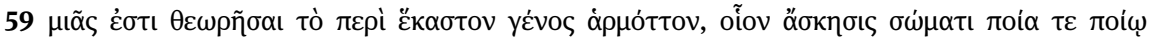

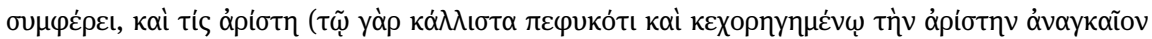

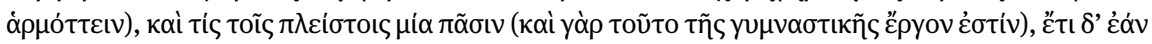

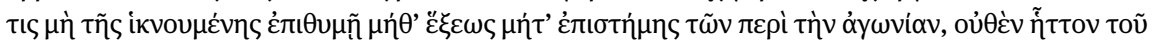

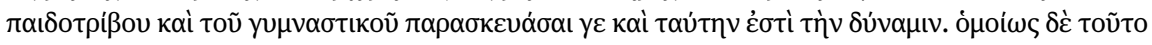

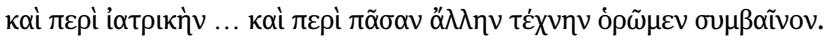


As the last line indicates, these four requirements hold not only for the gymnastic trainer's art, but also for the medical art and indeed every art. I will discuss each requirement as it applies to the medical art, though I will not stick to the order of the text.

Perhaps most importantly, the doctor must consider (2) what is the absolutely best treatment and this will be the treatment of the body that is most suited to receive health and resist disease. ${ }^{60}$ Such a body will also best reveal the nature of health: "One must certainly look for what is natural in things that are conditioned according to their nature, not in corrupted things; therefore, we must look at the human best conditioned according to body and soul-in whom what is natural will be clear ... " (Pol I 5, 1254a36-9). Optimal health, as revealed in the body most suited to receive it, would also seem to be the primary aim of the medical art (cf. Pol I 9, 1257b25-8, discussed in Section 4). ${ }^{61}$ Consequently, it would fall to the doctor to optimize or enhance a patient's body so that it may be more capable of receiving health. Indeed, Aristotle seems to assume this in Politics VII 16 when he says that legislators should be concerned about the bodies of their future citizens (1335a4-6) and that couples should consult "the advice from doctors concerning procreation" (1335a39-40).

The doctor will also know how to treat those bodies not suited for optimal health. The doctor should consider (1) how different modes of treatment are suited to different bodies and (3) what sort of treatment is best adapted to the majority of humans. ${ }^{62}$ The latter will be especially important for determining general medical treatment and advice. The doctor should also know (4) how to impart any lower degree of health, and the passage suggests that this might be needed because the patient may prefer not to have the greatest level of health available to him. As we noted in Section 4, the doctor may respect such preferences, but it is not the medical art itself that tells him to do so.

With respect to this last requirement, we should also observe that the doctor can "give excellent treatment even to those who can never enjoy health" (Rhet I 1, 1355b12-14); like every craftsman, the doctor does his best with the inferior matter he must work with (NE I 10, 1100b35-1101a6). Yet he always aims at health, as may be inferred from de Caelo II 12:

Take health as the end. One man is always healthy, another becomes healthy by slimming down, another by running and slimming down ... while another cannot attain health, though

60 Relatedly, when discussing the second species of quality, Aristotle notes that some bodies are called "healthy" because they are well suited to preserving health (Cat 8, 9a21-4).

61 Cf. Tracy (1969, 314-18).

62 See also Tracy (1969, 318-9 and 327-8), who notes that the absolutely best form of health cannot be attained at every stage of life or by every member of the species. 
he can attain running or slimming down. There are different ends for these different men. For while it is certainly best for all to attain the end; yet, if that is not possible, it is always better, the closer one is to the best. $(292 \mathrm{~b} 13-19)^{63}$

This example seems to come from the practice of medicine. ${ }^{64}$ When a doctor treats a patient who is incapable of health, does the doctor aim at health? Aristotle's answer seems to be that he does in one way but not in another. The doctor does not aim at health insofar it is not achievable, but he does aim at health insofar as he aims at the healthiest state available to the patient and one unhealthy state is better than another only insofar as it is "closer to"-i.e., better approximates and participates in-health. Thus, Aristotle seems to suppose that even when treating an incurable patient, the doctor should be guided by the goal of health.

\section{The Medical Art can Produce both Health and Disease}

We have seen that Aristotle understands the medical art to be a productive "state" (hexis) that involves a true account (Section 5), and yet he also characterizes the medical art as a certain kind of "potentiality" or "power" (dunamis). ${ }^{65}$

This notably occurs in Metaphysics $\Theta 2$ where Aristotle articulates some differences between rational and nonrational powers-the former of which are found in the rational part of the soul, and the latter in non-living things and in the nonrational part of the soul (1046a36-b2). All arts, i.e., "productive expertises" (1046b3), are rational powers. Like all powers, they are "principles of change in another thing or [in the same thing] as other" (Meta $\Theta$ 2, 1046b3-4; cf. $\Theta 1$, 1046a11-13 and $\Delta 12,1019 \mathrm{a} 15-16)$; the medical art, in particular, is a principle of change in the one who is being healed, where this is either someone else or the doctor himself but considered as other. Conversely, "medical ability might be in

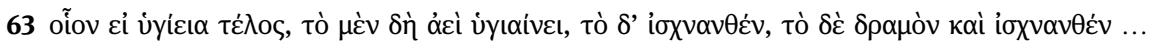

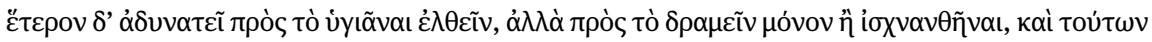

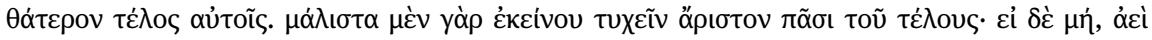

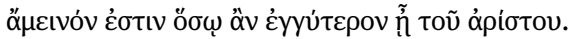

64 Cf. Elders $(1965,239)$, who also notes that ischnainō (here translated "slimming down") is a medical term.

65 Beere (2009, 81n.20) offers some reasons for why Aristotle would call art (technē) a "state" (hexis) in Nicomachean Ethics VI and a "power" (dunamis) in Metaphysics $\Theta$. 
the man who is being healed, but it is not in him qua being healed" (Meta $\Delta 12$, 1019a17-18).

Aristotle then gives an example of a nonrational power ("the hot") and of a rational power ("the medical art”), and he explains why they differ:

The hot is <the cause $>$ of heating alone, but the medical art is <the cause $>$ of health and disease. The reason is that expertise [epistēmē] is a rational account [logos], and the same rational account reveals a thing and its privation, but not in the same way. It is in a way of both, but it is more of the positive being [tou huparchontos]. Therefore, such expertises must be of contraries, but of one in accordance with their natures and of the other not in accordance with their natures; since the rational account pertains to one object in accordance with that object's nature, and to the other, in a way, incidentally [kata sumbebékos]. For it reveals the contrary by negation and removal; privation is the primary opposite and the removal of the other opposite. (Meta $\Theta 2$, 1046b6-15) ${ }^{66}$

Here Aristotle maintains that the medical art can produce health and disease because it consists in a rational account (logos, 1046b7) of health. This is because the same rational account explains both the positive form and its privation, health is the positive form and disease is its privation (see Section 3), and consequently, the single account of health explains both health and disease. ${ }^{67}$ Nevertheless, the medical art is concerned with health in accordance with its nature, and disease not in accordance with its nature but incidentally (Meta $\Theta 2$, 1046b10-13). ${ }^{68}$ Aristotle explains this by the fact that while one understands the positive form in itself, one understands the privation not in itself but only through the positive form, by being the privation of that form (1046b13-15; cf. DA I 5, 411a3-7; III 6, 430b20-3). Thus, while one understands health in itself, one

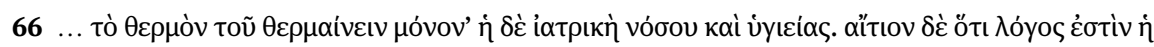

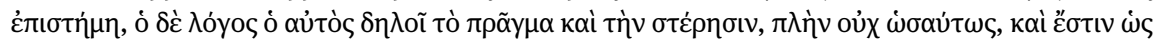

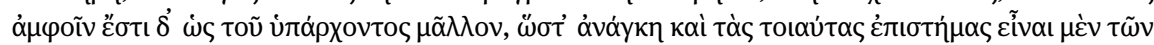

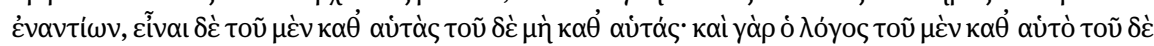

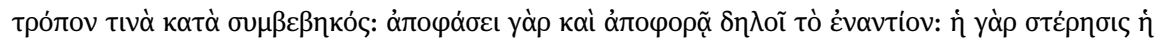

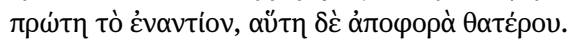

67 Two points are worth making. First, even though Aristotle describes medicine as an account of health, medicine grasps the nature of health in a distinctively productive way, as we noted in Section 5, on which point, see also Beere (2009, 80-2). Second, Aristotle implies at Metaphysics $\Theta$ 2, 1046b11-15 that all contraries are related to one another as positive form to privation, and so every expertise is of contraries in the way described (on which see also DA III 1, 427b6; $N E \mathrm{~V} 1$, 1129a11-16; APr I 1, 24a21; Phys VIII 1, 251a30; Meta K 3, 1061a18-20; etc.).

68 Aristotle says "in a way, incidentally" because there is more than one way of being employed incidentally, on which see e.g., Eudemian Ethics III 4, 1231b38-2a3. For example, the doctor does not produce disease incidentally in the same way that the doctor builds a house incidentally (Phys I 8, 191b4-6). 
understands disease not in itself but only through health, by being the privation of health. ${ }^{69}$

In this way, Aristotle provides a metaphysical grounding for the medical art's inherent orientation to health. This involves two key claims: (1) health is a positive form and disease a privation of health, and (2) the medical art consists in a logos, which is essentially of the positive form. If the medical art were a mere kind of experience (see Section 5), it would not grasp the logos of health and so would not have an inherent teleological orientation (or at least not in the same way). ${ }^{70}$ Yet the medical art does grasp the logos of health, and this has consequences for it as a productive power: it produces health in accordance with its nature, and disease not in accordance with its nature, but incidentally.

The philosophical framework of Metaphysics $\Theta 2$ is also in the background of Eudemian Ethics II 10, where Aristotle draws the further conclusion that producing disease is actually contrary to the nature of medicine. ${ }^{71}$ Aristotle is discussing deliberation, and writes:

The end is by nature always a good, and concerning this, one deliberates with respect to particulars [kata meros]. For example, a doctor would deliberate about whether he should give a drug, and the general about where he should camp. In these cases, the unqualifiedly best end is a good. Yet contrary to nature and by distortion [dia strophēn] not the good but the apparent good [is the end] ... From expertise [apo epistemmēs] it is possible to do what is not proper to that expertise; for the same expertise is not similarly productive of health and

69 This is why the medical art, though capable producing health and disease, should nevertheless be thought of as "the form of health in the soul" (Meta Z 7, 1032b13; cf. $\Lambda$ 3, 1070a29-30). The medical art is not "the form of disease in the soul" because disease is not a form but a privation of form, and it is only form that can be known it itself. Anagnostopoulos $(2007,25)$ mentions Metaphysics $\Theta$ 2, but he does not explain that the privation is known through the positive form. This may be because he tends to assimilate the views of Plato and Aristotle, and as Beere (2009, 88n32) suggests, Plato does not possess Aristotle's metaphysical explanation for why each art is oriented toward the good, on which see also Baker (2017, 1847n.19).

70 This also helps us to appreciate why the inherent teleology of the medical art is not adequately explained by the fact that medicine comes to be in order to fill a certain need of human naturecontra the picture seems to be suggested by Anagnostopoulos $(2000,272)$ and $(2007,30-32)$. This is because medical experience (empeiria) and medical expertise (epistēmē) both come to be in order to fill the same natural need, but it is only the latter that possesses an inherent teleological orientation due to a logos.

71 The passage is not generally discussed, though in his commentary on the passage, Woods $(1992,149)$ notes the connection with Metaphysics $\Theta 2$. 
disease, but of the former in accordance with its nature [kata phusin], and of the latter contrary to its nature [para phusin] (1227a18-28). ${ }^{72}$

Here Aristotle emphasizes the metaphysical priority of the good over the apparent good. Every art is ordered to an end, which is a good by nature (1227a21; cf. Section 2), and this good corresponds to what Metaphysics $\Theta 2$ called "the positive being" (to huparchon, 1046b10). ${ }^{73}$ To achieve the art's proper good is in accordance with the nature of the art. Yet in virtue of being a rational capacity, every art can also produce the contrary of its proper good, but to do so is contrary to the nature of the art (1227a28). Accordingly, since disease is the contrary of health, producing disease is contrary to the nature of the medical art. ${ }^{74}$ It is a "distortion" of the medical art (1227a21-2; cf. Protrep B12; Top VI 5, 143a3-8; Prob 30.8).

In this passage, Aristotle also implies that whenever the doctor is deliberating or acting, he "always" takes health as his end (EE II 10, 1227a18; cf. II 11, 1227b2533). The same thought is found in the parallel passage of the Nicomachean Ethics: "We deliberate not about ends but about what contributes to ends. For a doctor does not deliberate whether he shall heal ..." (III 3, 1112b11-13). ${ }^{75}$ One might object that of course doctors do deliberate about whether to heal and that some actually decide not to heal. However, Aristotle's point is surely that when a doctor deliberates about whether to heal, he is not doing so as a doctor. To deliberate or act as a doctor one must do so in accordance with the nature of the medical art, and this requires the doctor to take health as his end-that is, it requires the doctor to have the intention to heal (cf. Meta $\Theta 5,1048 \mathrm{a} 11) .{ }^{76}$ This intention even seems to partly constitute the proper activity of the doctor, since healing, as we noted

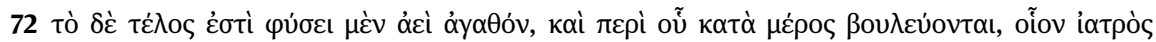

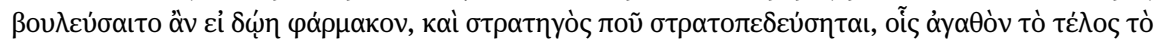

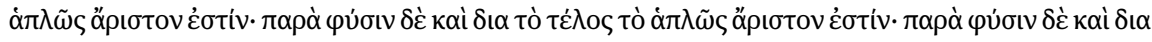

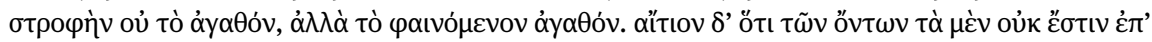

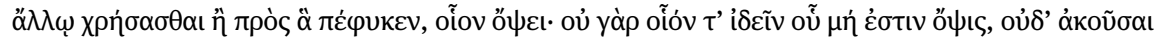

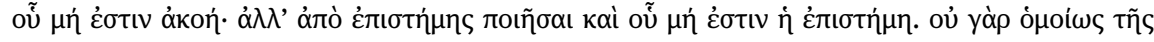

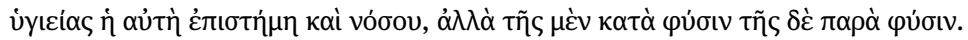

73 Cf. Baker (2017, 1845-7).

74 Commenting on Metaphysics $\Theta$ 2, Johansen $(2017,118)$ writes, "While medicine may enable you to kill, in killing you are not realising what medicine is really about." Yet Eudemian Ethics II 10 makes it clear that Aristotle's view is stronger: in killing you are acting contrary to the nature of the medical art. On the political implications of this claim, see below.

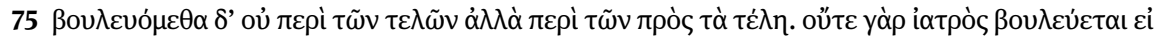

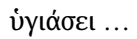

76 However, this is not to say in order to be active as a doctor one must always have occurrent thoughts about health as the goal of his action. In this respect, I take what I say to be compatible with a non-psychologistic understanding of art, on which see e.g., Fernandez and Mittlemann (2017). 
earlier, is essentially ordered to health as an end (cf. Meta $\Theta 6,1048 \mathrm{~b} 18-35$ ). Nevertheless, the mere possession of the art of medicine does not imply the intention to heal or to employ the art at all (cf. DA III 9, 433a4-6). ${ }^{77}$

If we combine the thoughts of Metaphysics $\Theta 2$ and Eudemian Ethics II 10, we can also see that there may be some incidental uses of the medical art that are nevertheless not contrary to the nature of that art. For while Eudemian Ethics II 10 suggests that producing disease is contrary to the medical art because disease is the opposite of health, Metaphysics $\Theta 2$ implies that if one should use the medical art to produce anything that is not health (or not ordered to health), that would be an incidental use of the art. Thus, if one should use the medical art to produce something that is neither health nor disease, one would be using the medical art incidentally but not contrary to its nature. It also seems like there can be such uses: whenever one understands how to produce health, one also understands many ways to manipulate the body. For example, if one knows the uses of "honey, wine, hellebore, cautery and cutting” for producing health, one also knows about their effects for producing other things (NE V 9, 1137a12-17), and if one should use the medical art to produce these other things-e.g., pleasure or pain, heat or cold, supposed beauty or ugliness - the medical art will be the cause of them only incidentally.

We can accordingly distinguish three different uses of the medical art. First, one can use the art properly-that is, in accordance with the nature of the medical art, and here the doctor would use the medical art to produce health. Second, one can use the art only incidentally, that is, neither in accordance with the nature of the medical art nor contrary to it, and here the doctor would use the medical art to produce something that is neither health nor disease. Third, one can use the medical art both incidentally and contrary to its nature, and here the doctor would use the medical art to produce disease, understood as the privation of health. It is possible to use the medical art in these three different ways only because the medical art is a rational expertise with an inherent teleology that cannot be altered by the patient, the doctor or even the state.

\section{Medical Care, Political Wisdom, and the Hippocratic Oath}

Aristotle's account of the medical art has ramifications for politics. To see how this is so, we should first observe that Aristotle's politically wise person would no

77 And so, art is still relevantly contrasted with moral virtue, pace Angier (2010, 48): the latter does, but the former does not determinately dispose one toward the proper good (cf. EE VIII 1, 1246a31-b4). See also footnote 85 below. 
doubt want to use the medical art in order to promote the health of the citizens, and he would do so by relying on the advice of doctors and even by employing them in public service. ${ }^{78}$ Indeed, we should expect as much (Section 4): the politically wise person aims at the happiness of the state and its citizens (NE I1-2; Pol II 5, 1264b1719), health is a necessary precondition for happiness (e.g., NE VII 13, 1153b16-18), and all the arts are properly subordinated to political wisdom (NE I 2, 1094a26-b7).

As a result, the politician will need to have some principled way to decide what counts as "medical care". At first it might seem easy to determine what should count as medical care-perhaps "care that doctors give" or "care that promotes health" - but an Aristotelian will understand these are not adequate answers since the medical art can be used incidentally as well as properly (Section 7), and that some things are called "healthy" only by an extended use of the term and so do not at all fall under the scope of medical expertise (Section 6). Instead, "medical care" must be determined by reference to the inherent nature of the medical art. Aristotle would seem to imply this in Metaphysics $\Gamma 2$, when he comments that the term "medical", just like the term "healthy", is used pros hen and so a medical "work" (ergon) should be understood as a work "of the medical art" (1003b3), that is, a work of the medical art as such. This would be a work that is performed by, and in accordance with the medical art; thus, "medical care" should likewise be understood as care that is performed by, and in accordance with the medical art.

This is not, of course, to say that a politician will be obliged to offer to the citizens anything that can be properly called medical care. As we noted in Section 4, the political art sets a limit to the medical art's pursuit of health, and so will likewise set a limit to public medical care. Nevertheless, the politician will recognize that it is the nature of the medical art itself that sets the boundaries for what can properly be called "medical care", For example, only those bodily enhancements may be considered medical care that would enable the body to attain (or to come closer to attaining) optimal health (Section 6); by contrast, enhancing the body's ability to run could not be considered medical care. We will discuss the

78 In Politics I 10, Aristotle says that the household manager (oikonomos) considers health in one way and the doctor in another, and Aristotle also indicates that household management uses the medicine as a "subordinate art" (huperretikē) to promote the health of the members of the household (1258a31-4). Because household management (oikonomia) is one form of practical wisdom just like political wisdom (NEVI 8, 1141b32), we can reasonably infer that the political wise person will similarly use the medical art to promote the health of the citizens and the polis as a whole (cf. Pol VII 11, 1330a34-b17). Plato in the Republic also clearly envisages the government both using and regulating the medical art (esp. III, 405a-410b). Moreover, Nutton (2013, 87) writes: "If Herodotus [Histories 3, 131] is to be believed, there was already a system of public doctors in Aegina and Athens by the late sixth century, for Democedes held such a post in both cities." 
boundaries of medical care more fully in the next section, where we focus on issues relating to death and dying.

Here I instead want to note that the Aristotelian politician, who must rely on the medical art in various ways, also understands that the medical art is in danger of being distorted-even systematically. Aristotle mentions one cause of such distortion in Politics I 9 where he explains that even though the end of the medical art is health, "some people turn every <art> into the wealth-making art-supposing that wealth is the end and that everything must contribute to the end" (1258a1214). Such money-lovers might distort medicine in many ways-e.g., by misidentifying health, by elongating the process of healing, or by obeying the wishes of paying patients even when this involves destroying their bodily health. The politician would surely not want the medical art to be systematically distorted, and he will have various reasons for this. We will mention some of these reasons in our last section, but one is already clear: a distorted medical art will impede the politician's efforts to make the citizens healthy and happy. Consequently, the politician will wish to regulate the medical art, and Aristotle seems to think that it is proper for political wisdom to regulate (at least to some degree) how the medical art and indeed all the arts are studied and exercised (NE I 2, 1094a28-b7).

Aristotle at one point casually implies that there should be some regulation of the medical art. In the course of an argument about who should rule in the state, he writes:

Just as a doctor should give an account [tas euthunas] in the presence of doctors, so should any other man give an account in the presence of his peers. Yet it is not only the common practitioner [demmiourgos] who is a 'doctor,' but also the master of the art [architektonikos], and third, the man educated in the art [pepaideumenos]. In pretty much all the arts, educated people exist, and we attribute [the power of] judging to educated people no less than to those who know. (Pol III 11, 1282a1-6) $)^{79}$

The word euthuna normally indicates a public examination of officials (cf. Athenian Constitution 48.4), and so the term here may suggest that doctors should be publicly giving an account, perhaps by an arrangement of the government. Aristotle also clarifies that a doctor should give an account in the presence of fellow doctors, and this suggests that the examination is not (primarily) ethical but rather based on those standards that arise from the inherent nature of the medical art.

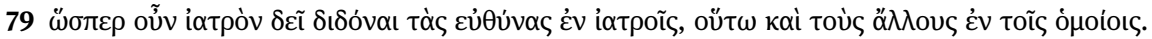

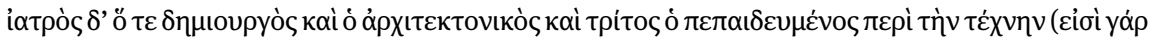

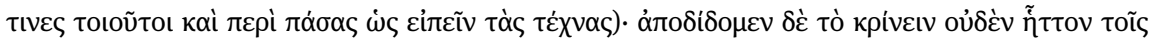

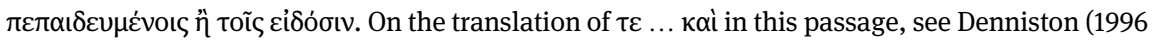
[1950], 515 [s.v. $\varepsilon$ I.7]). 
Aristotle explains that the examining doctors may include a common practitioner (dēmiourgos), a master of the medical art (architektonikos), and someone who does not strictly know the art but is nevertheless "educated" in it (pepaideumenos). All would apprehend the general nature of medicine, but each would be especially sensitive to different aspects. For example, the common practitioner would be keenly aware that a fair amount of experience (empeiria) and training is necessary in order to practice medicine competently (Section 5). The master of the art best appreciates how medicine is dependent on natural philosophy, and so he would be quick to object to any doctor who makes claims that are incompatible with the truths of biology (Sections 5 and 6). Additionally, the person "educated" in the medical art would seem to be someone who is especially aware of the nature and limitations of the art, ${ }^{80}$ and so he would be sensitive to the different ways in which the term "healthy" is used (Section 6) and he would appreciate the trifold distinction articulated earlier-namely, that some activities of a doctor are in accordance with the nature of the medical art, some contrary to it, and some neither in accordance with nor contrary to it (Section 7).

Of course, if doctors should be publicly called to account, then we should expect there to be some generally accepted standards for medical practice, and this brings us to the Hippocratic Oath. Though Aristotle never mentions the Oath, he may still be aware of it; he does consider Hippocrates a "great" physician (Pol VII 4, 1326a14-16) and he displays some familiarity with the Hippocratic corpus. ${ }^{81}$ However, even if Aristotle had never read the Oath, he was probably familiar with the tradition that gave rise to it, and one might not implausibly suppose that Aristotle's own account of the medical art is, at least in part, a philosophical reflection on that tradition. Like Hippocrates, Aristotle was an Asclepiad. ${ }^{82}$

I will not here offer an Aristotelian interpretation of the Oath as a whole, but I will say how Aristotle might think about the following important passage, which occurs just after the doctor has promised to use his treatments for the benefit of the

80 See van der Eijk (1995, 451n.18) and Jori (1995) who discuss the pepaideumenos. Two relevant passages that van der Eijk and Jori do not consider are NE I 3, 1094b23-a1 and Meta $\Gamma$ 4, 1006a5-8. 81 On Aristotle's familiarity with the Hippocratic Corpus, see Oser-Grote (2004), though she does not specifically discuss the Oath. See also Jouanna (1999, 401-2), who observes that even though the authorship and date of the Oath have been disputed, the "Oath was always attributed by the ancients to Hippocrates" and the date is often taken to be the fifth or fourth century BC.

82 An Asclepiad is a member of a family that traced its descent back to Asclepius. For reason to think Aristotle was an Asclepiad, see the evidence listed in Natali (2013, 8-9), which includes the reference found in the second sentence of this paper. For reason to think Hippocrates was an Asclepiad, see Phaedrus 270c3-5. There is also reason to think that the Hippocratic Oath was created in order to secure the safe transmission of medical knowledge outside the Asclepiad clan, on which see e.g., Jouanna (1999, 50-1). 
sick and not for their harm (10-11). The doctor swears: "I will give no deadly drug, even when asked to do so, and I will not advise about such a course of action. Similarly, I will not give a destructive pessary to a woman. Purely and piously I will guard my manner of life and my art" (13-17). ${ }^{83}$ Here, the doctor seems to foreswear using the medical art to kill. ${ }^{84}$ In the last sentence, we seem to find the explanation for why the doctor is doing this: he intends to guard his manner of life (ßíos) and his art ( $\varepsilon \varepsilon \chi v \eta \dot{)}$. An Aristotelian interpretation might run as follows. Because the medical art is a rational power, it can be used incidentally and even contrary to its nature. Using the medical art to produce disease, especially disease that results in the death, is always contrary to the nature of the medical art, and this is the case no matter the circumstances-e.g., even if the patient may wish to die, and even if the state has decreed that the patient must die. If doctors should wish to "guard" against systematic distortions of the medical art, they would naturally wish to come up with something like the Hippocratic Oath. If one strongly identifies as a doctor, then observing the Oath would be also a way of guarding one's "manner of life" as well. ${ }^{85}$ The responsible politician would no doubt encourage the creation of such an oath because he has a vested interest in preserving the inherent nature of the medical art. ${ }^{86}$

Aristotle would likewise give a teleological interpretation to a similar prohibition in the Hippocratic Epidemics: "Concerning diseases, practice two things: to help or to [at least] do no harm. The art [exists] in relation to three

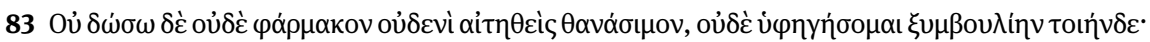

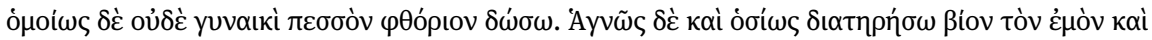

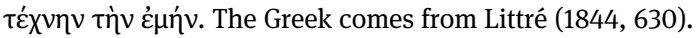

84 See van der Eijk $(2005,102)$, Nutton $(2013,344 n .90)$ and especially Cavanaugh $(2018,58-64)$ for this straightforward interpretation of the passage. Edelstein (1943) influentially argued that the prohibition was the expression of peculiarly Pythagorean views, but his view is now generally rejected and see e.g., Anagnostopoulos (2000) for a critique.

85 See Cavanaugh $(2018,27-8)$ who uses Rhetoric I 1, 1355b15-21 to argue that the term "doctor" may be used in two ways-as either designating someone who merely possess the art or as someone who both possesses it and uses it for its proper end. See also NE III 3, 1112b11-13, discussed in Section 7, in which passage Aristotle seems to use the term "doctor" in this latter way. 86 Cavanaugh (2018) and Anagnostopoulos (2000) seem to take seriously the view that author of the Oath might be sensitive to the teleology that derives from the medical art itself. However, Cavanaugh $(2018,85)$ would seem to identify the end of the art as "caregiving" and he eventually argues for an "ethic internal to medical practice" that cares for its "internal goods" (130-2) thoughts that seem to me more similar to those of MacIntyre (1984, 187-203) than those of Aristotle, on which see footnote 98. My account has more in common with that of Anagnostopoulos (2000), though he does not interpret the Oath as a way to protect the integrity of the art itself, and I cannot fully agree with his claim that there is a "requirement imposed on the physician to treat a patient” and that this derives from medicine itself (Anagnostopoulos, 2000, 270). See also Anagnostopoulos (2007) and the response from Rudebusch (2007). 
things: the disease, the diseased person and the doctor. The doctor is the servant [upēretēs] of the art, and the diseased person must oppose the disease with the help of the doctor" (1.2.5.9-13). ${ }^{87}$ In what sense is the doctor the "servant" of the medical art? The Aristotelian interpretation would run as follows. A servant takes his ends and goals from his master (Pol I 4). If the doctor is the servant of the medical art, the doctor must take his end from the medical art. In order for the doctor to take his end from the medical art, the medical art must inherently have an end. Thus, the medical art inherently has health as its end, and this is why it would be a misuse of the art to harm the patient. Aristotle would presumably think that, even though this passage does not use explicitly teleological language, the author is nevertheless attempting to recognize the teleological character of the medical art. ${ }^{88}$

\section{Death, Dying and the Medical Art}

Aristotle thinks that humans have a sort of natural aptitude for recognizing the truth (cf. Rhet I 1, 1355a14-18), and so he would think that someone familiar with medicine would instinctively recognize that its end is health. However, Aristotle also thinks that one can recognize a truth in a general way without really understanding it and without being able to expound or defend it (cf. Meta A 1, 981a7-b13; $\alpha$ 1, 993b5-7). In this section, I want to help us appreciate the philosophical achievement of Aristotle's account of medicine, and I will do so by showing how he would respond to various challenges to the idea that killing a patient is contrary to the art of medicine.

Someone might, for example, argue that it is sometimes proper for a doctor to kill a patient because the end of the medical art is "to make human life better" 89 and sometimes death is good for the patient. (One might accordingly read the Epidemics passage above as implying that the end of the medical art is not health but "benefiting the patient" in general.) By contrast, Aristotle would observe that in order to know what is truly beneficial for the patient, one would need to know

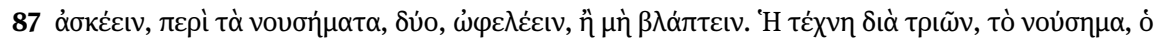

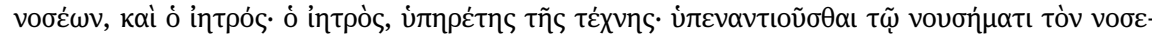

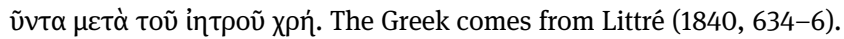

88 Craik (2017) detects various aspects of teleological thinking in the Hippocratic Corpus, and she takes herself to be alone in doing so. She does not consider Epidemics 1.2.5, but I suggest that at least Aristotle would see teleological thought at work here.

89 Velleman (1992, 667). 
what is a human's highest good, which people generally call "happiness," and this falls under the expertise of the ethicist and politician but not under the expertise of the doctor as such (Section 4). Because the end of an art must of course fall under that art's expertise, "happiness" or "making human life better" could not be the end of medicine (Sections 5 and 6). ${ }^{90}$ Moreover, it would be futile to attempt to narrow in on the medical art by simply restricting the means of "making human life better" to e.g., "relieving pain,"91 and this is because knowing when relieving pain would be improving a patient's life still requires knowing what is good for the patient overall, and this knowledge is not possessed by the doctor as such. ${ }^{92}$

Yet someone might resist Aristotle's view for other reasons-perhaps by arguing that if the end of medicine were health, "physicians would have no role to play in the care of dying patients."93 However, as we saw in Section 6, Aristotle thinks the doctor still aims at health even when he "gives excellent treatment to those who can never attain health" (Rhet I 1, 1355b13-14). This is because the doctor aims at the best of the unhealthy states available (NE I 10, 1100b35-1101a6), and one unhealthy state is better than another only because it is "closer to" health (Cael II 12, 292b19). Thus, when the doctor as such treats an incurably sick patient by prescribing pain-relieving drugs or by administering other palliative care, he does so because the expected results of such care are somehow an approximation to health. ${ }^{94}$ Such approximations could take various forms, and patients could choose the form they find most suitable.

What if a patient requested assistance in committing suicide, claiming that by dying he would achieve a greater degree of "mental" or "spiritual health"? Plato would have been somewhat sympathetic to thoughts like this: he has Socrates argue in the Phaedo that the soul is better off when it is separated from the body

90 Aristotle would of course also consider "making human life better" to be an incomplete activity and so not an end, metaphysically speaking (cf. Section 2).

91 Velleman (1992, 667).

92 From this last point and our previous discussion in Section 4, it is also clear that Aristotle would consider the WHO's definition of health to be far too expansive: "a state of complete physical, mental and social well-being and not merely the absence of disease and infirmity" (1946, preamble).

93 Gill $(2005,61)$.

94 By contrast, as Anagnostopoulos $(2000,273)$ interprets Aristotle, "The reason they [the relieving of pain and suffering] are a part of medicine's aim is that a life without or with less pain or suffering is preferable to a life with or with more pain and suffering. In other words, in aiming to reduce pain or suffering the physician aims to improve life.” However, as I interpret Aristotle, it does not at all belong to the doctor, as such, to judge that a life with less pain is preferable to a life with more pain. This is because such a judgment requires knowing what is good overall for the patient, and this knowledge is not the proper to the doctor, as such. 
(66d7-7b1). ${ }^{95}$ Aristotle, however, does not think the soul is better off when separated from the body (Section 4), and more importantly, he makes it clear that the medical art properly concerns "health" understood as a virtue of the body (Section 3). Other "healthy" things fall under the expertise of medicine only insofar as they are definitionally related to this primary case of health (see Section 6); thus, the socalled "spiritual health" achieved by separating the soul from the body could only be "health" by an extended or metaphorical use of the term. Hence any doctor who used the medical art to destroy bodily health, even when aiming at mental or spiritual health, would not be giving medical care and would be acting contrary to the medical art.

Of course, as we also noted earlier, a patient may also have good reasons for not pursuing the highest degree of health attainable, and this may occur near the end of life when the patient may choose not to pursue every possible medical means of staying alive. A doctor may respect these wishes and not treat a patient against his will. But the doctor does not do so insofar as he is doctor; for the medical art pursues health "in an unlimited way" (Pol I 9, 1257b25). Nevertheless, in refraining from using the medical art, a doctor is not thereby acting contrary to the medical art. In order to act contrary to the medical art, one must use the medical art and use it in a way that is contrary to its inherent end. There may, of course, be some cases where refraining from using the medical art would be unjust-for example, when a doctor has already received appropriate payment (cf. $N E \mathrm{~V}$ 5, 1133a14-18). Yet this alone does not make something contrary to the art: the medical art is inherently teleological but not inherently ethical. ${ }^{96}$

We have now seen how Aristotle would address various challenges to the view that using medicine to kill is contrary to the nature of the art. Let us now ask two final questions.

95 After Socrates has drunk the hemlock and is in the process of dying, he tells Crito that he owes a "cock to Asclepius" (118a7-8)-Asclepius being the God of healing. One popular interpretation of this comment has been that Socrates considered his liberation from the body to be a kind of healing, on which see the references listed by Most $(1993,100)$. Nevertheless, we should also note that Socrates of the Phaedo considers suicide impermissible because we are not allowed to destroy the gods' property and we are their property (62a-e), on which see Cooper (1999).

96 Here three comments are in order. First, there are occasions when refraining to treat a patient would be a use of the medical art, and this could occur for various reasons-for example, the doctor might judge that the patient will recover best without treatment. Second, there may be occasions when refraining to treat would be contrary to the medical art-for example, when refraining to treat might change a process of healing into one of injuring. Third, there may be occasions when refraining to treat a patient might be contrary to a medical "manner of life" (bios), even if it is not strictly contrary to the medical art, on which see the two uses of the term "doctor" discussed in footnote 85 . 
First, what would Aristotle say to someone who claims that, even though doctors should not kill, we should instead have "thanatological" experts who specialize only in killing? I believe that we can gather an answer from Aristotle's metaphysics of medicine (Section 7). If the thanatologist expertly produces death by producing disease, then he must also understand the nature of the disease that he is producing and this will require knowledge of health. This is because disease is a privation of health and so must be understood through the positive form of health. However, because expertise is always properly of the positive form and incidentally of the privation, the thanatologist would be using his expertise of health to produce disease and death. Consequently, we should understand "thanatological" expertise as no distinct expertise but rather a corruption and distortion of the medical art. $^{97}$

Second, does Aristotle's account entail that it is always contrary to the medical art to produce disease? The answer must be: in one way, yes, and in another way, no. For the body as a whole may be called healthy and a bodily part may be called healthy, but the doctor primarily aims at the former and only secondarily at the latter. Thus, it is always contrary to the medical art to destroy the health of the whole body, but it is only generally (but not always) contrary to the medical art to destroy the health of any part of the body. This is because some bodily parts are more important than others with respect to the health of the whole body (see $E E$ VIII 3, 1248b14-16, quoted in Section 3). Thus, a doctor might remove a bodily organ or destroy its health in order to preserve the health of more important bodily organs and thereby the health of the whole body (cf. Pol VIII 1, 1337a27-30), but a doctor, as a doctor, will not destroy the health of an organ unless that will promote the health of the whole body. Even if patients should claim that the destruction of certain organs would promote their happiness or mental health, that will not matter. The doctor as such does not aim at happiness but at bodily health (Section 4 ), and mental health falls under the doctor's expertise only via pros hen predication (Section 6).

\section{Conclusion: Further Reasons to Protect the Medical Art}

"The end of the medical art is health" (NE I 1, 1094a8). We have seen that Aristotle is prepared to explain and defend this (seemingly commonsensical) claim by

97 See Baker $(2017,1843)$ where I argue that Aristotle implies at Metaphysics $\Delta 16,1021 \mathrm{~b} 17-20$ that such corrupted arts and pseudo-expertises do exist. 
means of a philosophically sophisticated account of medicine. In that account, Aristotle delineates the teleological structure of medicine by making use of various powerful distinctions-e.g., between happiness and health, positive form and privation, experience and expertise, and mental health (pros hen) and mental health (by extension). Aristotle also recognizes that the medical art can be systematically distorted in practice, and he seems to think that it is proper for the politician to guard against such distortion by regulating the medical art. This is especially so because the politician will want to use the medical art in order to promote the health of the citizens and so must recognize that the inherent nature of medical art determines what can properly count as medical care (Section 8).

Nevertheless, the medical art is not inherently ethical or political (Sections 4 and 5). To this extent, there seems to be some tension between Aristotle's position and that of various neo-Aristotelian bioethicists, who maintain that medicine has an "internal morality" ${ }^{98}$ For Aristotle, there is nothing about the medical art itself that would morally prohibit a politician from making laws that would require doctors to use the medical art contrary to its nature. Such laws would need to be justified by reference to the common good of the polis. ${ }^{99}$ Thus, in order to determine whether the Aristotelian politician would be open to enacting laws that would permit doctors to help patients commit suicide, one would need to discuss Aristotle's views on selfkilling and how that might affect the common good. A proper discussion of these issues falls outside the scope of this paper, but we should appreciate one relevant passage from the Eudemian Ethics: "Those who die in order to avoid suffering, as many people do, are not brave. As Agathon says, 'Vicious mortals, undone by suffering, long for death.' Similarly, the poets recount how Chiron, even though he was immortal, prayed to die on account of the pain from his wound" (III 1, 1229b3830a4). ${ }^{100}$ Aristotle here seems to assume that virtuous people will not kill themselves

98 See, in particular, Pellegrino (2001), which includes further references. This approach is in part due to MacIntyre (1984), who famously argues that there are "goods internal" to practices-goods that do not directly correspond to what Aristotle calls the ends of arts.

99 Aristotle may seem to be entertaining such a law when he says that abortion should be performed in order to control the size of the polis (Pol VII 16, 1335b22-6). However, in this passage Aristotle also says that abortions must be performed "before sensation and life occur" (1335b24). As Kraut (1997) explains, Aristotle here "means that the embryo should be aborted before the sense organs are formed" (155), i.e., before the embryo acquires a sensitive soul "in virtue of which an animal is an animal" (GA II 3, 736b1). It is thus possible that Aristotle would think that the doctor is not here acting contrary to the medical art, at least insofar as the embryo cannot yet be properly called an "animal".

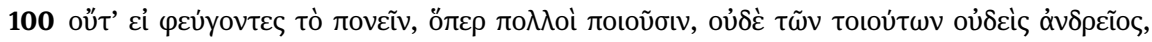

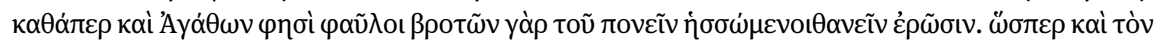

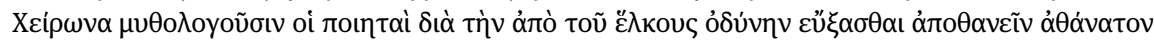

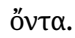


in order to avoid suffering or sickness. ${ }^{101}$ Given that the Aristotelian politician aims to make the citizens virtuous (cf. NE I 13, 1102a7-10; V 1, 1129b19-25; V 2, 1130b23-4), it seems that he could not allow suffering patients to kill themselves, even with the help of a doctor (cf. NE V 11, 1138a5-7). However, even if the politician could allow physician-assisted suicide, that would not make it medical care, and it will always be contrary to the medical art.

Moreover, Aristotle surely thinks that the politician will always have some good reason to regulate the medical art in such a way that its inherent nature is preserved. We have so far focused on one straightforward reason-namely, that an undistorted medical art will be more effective in promoting the health of the citizens-but there are a number of other interconnected reasons that one might glean from the text of Aristotle. In conclusion, I want to give you a sense of these various reasons by briefly discussing four in particular.

First, Aristotle thinks that the medical art has progressed (Pol II 8, 1268b32-8), and he also thinks that in order for an art to progress, its outline structure needs to be sound (NE I 7, 1098a22-26). Yet if doctors systematically distort the medical art by consistently using it in ways that are contrary to its nature, they will inevitably compromise the art's outline structure, and in this way impede the art's developmental progress.

Aristotle would also think, second, that a distorted medical art can impede one from achieving virtuous action. For example, both politicians and ordinary citizens need to rely on the expertise of doctors for a correct understanding of health (cf. Top II 2, 110a20-22), and the virtue of temperance-the virtue concerned with pleasures of the body-seems to require some adequate knowledge of health (NE III 11, 1119a16-18). Consequently, if politicians and citizens are given a distorted understanding of health by their doctors, temperate action will be impeded both individually and collectively.

Third, a systematic distortion of the medical art can alienate the patient from the doctor. Aristotle thinks that patients who wish to become healthy must obey their doctors (NE VI 12, 1143b30-3), but in order for this to occur, patients must trust their doctors (NE IX 2, 1164b22-5). However, this trust will surely be eroded (cf. Rhet II 1, 1378a6-8) when patients see their doctors presenting themselves as experts on matters that do not fall under their expertise, altering medical practice in order to make more money, or generally giving the impression that medicine does not exist for the sake of the patient's health.

101 Similarly, in the Nicomachean Ethics, Aristotle says that dying in order avoid pain is the act "of a coward" (III 7,1116a14), and he also characterizes suicide as an act of injustice toward the state (V 11, 1138a11). For some discussion of the last passage, see Cooper (1999, 526-31) and Gauthier and Jolif (2002 [1970], 425). 
Fourth and finally, Aristotle would also think that any doctor who uses the medical art contrary to its nature will inevitably be alienated from his product (cf. Top VI 5, 143a4-5). A suitable treatment of this issue must be reserved for another occasion, but the basic rationale is as follows. Every craftsman or artisan, as such, loves his proper product because it reveals the being of the art inside of him (NE IX 7, 1167b33-8a9). Thus, the doctor, as such, loves the health that he produces because it reveals the being of the medical art inside of him. Moreover, the doctor, as such, will take pleasure in healing and in the health he produces because each person takes pleasure in what he loves (NE I 8, 1099a7-11). However, disease does not reveal the being of the medical art because the medical art is essentially of health and only incidentally of disease (Section 7). Consequently, the doctor, as such, cannot love or take pleasure in the disease that he produces in the patient, and this is so even when that disease is causing the kind of death that the patient may desire.

Acknowledgments: For written comments on previous drafts of this paper, I thank David Kauffman, Benjamin Hole, Caleb Cohoe, Thomas Cavanaugh, Victor Caston, and two anonymous referees. For various helpful conversations and comments, I also thank Ted Poston, David McPherson, Kevin Meeker, Marsha Mansell, Mariska Leunissen, Gabriel Richardson Lear, Anne Jeffrey, Stephen Hill, Sherif Girgis, Christopher Frey, Michael Francis, Daniel O’Donnell, Jason Carter and audiences at the University of Mississippi, the 2017 Pacific division meeting of the American Philosophical Association, and the 2016 and 2017 meetings of the Alabama Philosophical Society.

\section{References}

Ackrill, J. L. 1980. “Aristotle on Eudaimonia.” In Essays on Aristotle’s Ethics, edited by A.O. Rorty, 15-33. Berkeley: University of California Press.

Ahonen, M. 2014. Mental Disorders in Ancient Philosophy. Cham: Springer.

Anagnostopoulos, A. 2017. "Change, Agency and the Incomplete in Aristotle." Phronesis 62: 170-209.

Anagnostopoulos, G. 2000. "Euthanasia and the Physician's Role: Reflections on Some Views in the Ancient Greek Tradition." In Bioethics: Ancient Themes in Contemporary Issues, edited by M. Kuczewski and R. Polansky, 251-90. Cambridge, MA: MIT Press.

Anagnostopoulos, G. 2007. "Ancient Greek Views on the Goals of Medicine and their Implications." Philosophical Inquiry 29 (5): 1-37.

Angier, T. 2010. Technē in Aristotle's Ethics: Crafting the Moral Life. London: Continuum. 
Anscombe, G. E. M. 1965. “Thought and Action in Aristotle." In New Essays on Plato and Aristotle, edited by J. Bambrough, 143-58. London: Humanities Press.

Aquinas, T. 1969. Sententia Libri Ethicorum, edited by Dominican Brothers. Rome: Commissio Leonina. Vol. 47 of T. Aquinas. (1882-ongoing). Opera Omnia. Rome/Paris.

Aquinas, T. 1985. Sentencia Libri De Sensu et Sensato, edited by Dominican Brothers. Rome: Commissio Leonina; Paris: J. Vrin. Vol. 45(2) of T. Aquinas. (1882-ongoing). Opera Omnia. Rome/Paris.

Aujac, G. (ed. and trans.) 1992. Denys d'Halicarnasse: Opuscules Rhétoriques, Vol. 5, Paris: Les Belles Lettres.

Baker, S. 2015. "The Concept of Ergon: Towards an Achievement Interpretation of Aristotle's 'Function Argument'." Oxford Studies in Ancient Philosophy 48: 227-66.

Baker, S. 2017. "The Metaphysics of Goodness in the Ethics of Aristotle." Philosophical Studies 174: 1839-56.

Barfield, O. 1973. Poetic Diction: A Study in Meaning. Middleton, CT: Wesleyan University Press.

Barnes, J. (ed.) 1995. The Complete Works of Aristotle, Vol. 1-2. Princeton: Princeton University Press. Sixth Printing with Corrections.

Barney, R. 2008. “Aristotle's Argument for a Human Function.” Oxford Studies in Ancient Philosophy 34: 293-322.

Beere, J. 2009. Doing and Being: An Interpretation of Aristotle's Metaphysics Theta. Oxford: Oxford University Press.

Burnyeat, M. 2001. A Map of Metaphysics Zeta. Pittsburgh: Mathesis Publications.

Burnyeat, M. 2004. “Aristotelian Revisions: The Case of 'de Sensu'." Apeiron 37 (2): 177-80.

Burnyeat, M. 2008. "Kinēsis vs. Energeia: A Much-Read Passage in (but not of) Aristotle's Metaphysics." Oxford Studies in Ancient Philosophy 34: 219-92.

Cambiano, G. 2012. "The Desire to Know (Metaphysics A 1)." In Aristotle's Metaphysics A: Symposium Aristotelicum, edited by C. Steel, 1-42. Oxford: Oxford University Press.

Cavanaugh, T. A. 2018. Hippocrates' Oath and Asclepius' Snake: The Birth of the Medical Profession. Oxford: Oxford University Press.

Cooper, J. M. 1999. “Greek Philosophers on Euthanasia and Suicide." In Reason and Emotion, 513-41. Princeton: Princeton University Press.

Craik, E. 2017. "Teleology in the Hippocratic Texts: Keys to the Future?." In Teleology in the Ancient World: Philosophical and Medical Approaches, edited by J. Rocca, 203-16. Cambridge: Cambridge University Press.

Denniston, J. D. 1996. (1950). The Greek Particles. 2nd ed., Indianapolis and Cambridge; Hackett; London: Bristol. Reprint.

Düring, I. (ed. and trans.). 1961. Protrepticus: An Attempt at Reconstruction. Göteborg: Acta Universitatis Gothoburgensis.

Edelstein, L. 1943. The Hippocratic Oath: Text, Translation and Interpretation. Baltimore: John Hopkins.

Elders, L. 1965. Aristotle's Cosmology: A Commentary on the De Caelo. Assen: Van Gorcum \& Co.

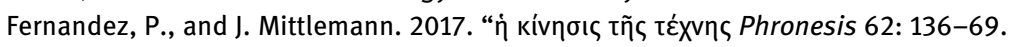

Fiedler, W. 1978. Analogiemodelle bei Aristoteles: Untersuchungen zu den Vergleichen zwischen den einzelnen Wissenschaften und Künsten. Amsterdam: Grüner.

Frey, C. 2007. "Organic Unity and the Matter of Man." Oxford Studies in Ancient Philosophy 32: 167-204.

Frey, C. 2015. "Two Conceptions of Soul in Aristotle." In Theory and Practice in Aristotle's Natural Philosophy, edited by D. Ebrey, 137-60. Cambridge: Cambridge University Press. 
Gasser-Wingate, M. 2016. “Aristotle on Induction and First Principles.” Philosopher's Imprint 16 (4): 1-20.

Gauthier, R. A. and J. Y. Jolif (trans. and comm.). 2002 (1970). L'Éthique à Nicomaque: Tome II - Commentaire Première Partie, Livres I-V. Louvain-la-Neuve: Éditions Peeters.

Gelber, J. 2018. "Two Ways of Being for an End." Phronesis 63 (1): 64-86.

Gill, M. 2005. “A Moral Defense of Oregon's Physician-Assisted Suicide Law.” Mortality 10 (1): 53-67.

Gonzalez, F. J. 2019. "Being as Activity: A Defense of the Importance of Metaphysics 1048b18-35 for Aristotle's Ontology," Oxford Studies in Ancient Philosophy 56: 123-191.

Harcourt, E. 2013. "Aristotle, Plato and the Anti-Psychiatrists: Comment on Irwin," In Oxford Handbook of Philosophy and Psychiatry, edited by K. W. M. Fulford et al., 47-52. Oxford: Oxford University Press.

Hasper, P. S., and J. Yurdin. 2014. "Between Perception and Scientific Knowledge: Aristotle's Account of Experience." Oxford Studies in Ancient Philosophy 47: 119-50.

Heinaman, R. 2007. "Eudaimonia as an Activity in Nicomachean Ethics 1.8-12." Oxford Studies in Ancient Philosophy 33: 221-53.

Irwin, T. H. 1999. Aristotle: Nicomachean Ethics. Translated with Introduction, Notes and Glossary, 2nd ed. Indianapolis and Cambridge: Hackett.

Irwin, T. H., 2013. "Mental Health as Moral Virtue: Some Ancient Arguments." In Oxford Handbook of Philosophy and Psychiatry, edited by K. W. M. Fulford, 37-46. Oxford: Oxford University Press.

Johansen, T. K. 2017. "The Logos of the Craftsman." Phronesis 62: 97-135.

Jones, W. H. S. (trans.). 1923. Hippocrates, Vol. 1. Cambridge, MA: Harvard University Press.

Jori, A, 1995. "Le pepaideumenos et la médecine", In Ancient Medicine in its Socio-Cultural Context: papers read at the congress held at Leiden University, 13-15 April 1992, Vol II, edited by H. F. J. Horstmanshoff, P. J. van der Eijk, and P. H. Schrijvers, 411-24. Amsterdam and Atlanta, GA: Rodopi.

Jouanna, J. 1999. Hippocrates. Translated by M. B. DeBevoise. Baltimore: Johns Hopkins University Press.

Kraut, R. 1979. “Two Conceptions of Happiness.” The Philosophical Review 88: 167-97.

Kraut, R. (trans. and comm.) 1997. Aristotle: Politics. Books VII and VIII. Translated with a Commentary. Oxford: Clarendon Press.

Kullmann, W. 1985. "Different Concepts of the Final Cause in Aristotle." In Aristotle on Nature and Living Things. Philosophical and Historical Studies, edited by A. Gotthelf, 169-75.

Pittsburgh: Matheisis Publications.

Lear, G. 2009. "Happiness and the Structure of Ends." In A Companion to Aristotle, edited by G. Anagnostopoulos, 387-403. Chichester: Wiley-Blackwell.

Leunissen, M. 2015. "Perfection and the physiology of habituation according to Physics VII. 3." In Aristotle's Physics: A Critical Guide, edited by M. Leunissen, 225-44. Cambridge: Cambridge University Press.

Littrè, É. (ed.) 1840. Oeuvres Complètes d'Hippocrate, 2, Paris: Baillière.

Littrè, É. (ed.) 1844. Oeuvres Complètes d'Hippocrate, 4, Paris: Baillière.

Lloyd, G. E. R. 2003. In The Grip of Disease. Oxford: Oxford University Press.

Lorenz, H. 2014. "Aristotle's Analysis of Acratic Action." In Cambridge Companion to Aristotle's Nicomachean Ethics, edited by R. Polansky, 242-62. Cambridge: Cambridge University Press. 
Lorenz, H., and B. Morison. 2019. “Aristotle's Empiricist Theory of Doxastic Knowledge.” Phronesis 64: 431-64.

MacIntyre, A. 1984. After Virtue. 2nd ed., Notre Dame: University of Notre Dame Press.

Makin, S. 2006. Aristotle: Metaphysics Book $\theta$. Oxford: Clarendon Press.

Menn, S. 2002. “Aristotle's Definition of Soul and the Programme of the De Anima." Oxford Studies in Ancient Philosophy 22: 83-139.

Moss, J. 2014. “Right Reason in Plato and Aristotle: On the Meaning of Logos.” Phronesis 59: 181230.

Most, G. W. 1993. “A Cock for Asclepius.” The Classical Quarterly 43 (1): 96-111.

Müller, J. 2018. "Practical and Productive Thinking in Aristotle.” Phronesis 63: 148-75.

Natali, C. 2013. Aristotle: His Life and His School, edited by D. S. Hutchinson. Princeton: Princeton University Press.

Nutton, V. 2013. Ancient Medicine. 2nd ed. Abingdon: Routledge.

Oser-Grote, C. M. 2004. Aristoteles und das Corpus Hippocraticum. Stuttgart: Steiner.

Pellegrino, E. 2001. "The Internal Morality of Clinical Medicine: A Paradigm for the Ethics of Helping and Healing Professions." Journal of Medicine and Philosophy 26 (6): 559-79.

Reeve, C. D. C. 1998. Aristotle: Politics, Translated with Introduction and Notes. Indianapolis: Hackett.

Reeve, C. D. C. 2017. Aristotle: De Anima. Translated with Introduction and Notes. Indianapolis: Hackett.

Rudebusch, G. 2007. "The Duty to Heal.” Philosophical Inquiry 29 (5): 38-50.

Sedley, D. 1991. “Is Aristotle’s Teleology Anthropocentric?.” Phronesis 36 (2): 179-96.

Shields, C. 1999. Order in Multiplicity: Homonymy in the Philosophy of Aristotle. Oxford: Oxford University Press.

Tracy, T. J. 1969. Physiological Theory and the Doctrine of the Mean in Plato and Aristotle. The Hague: Mouton.

van der Eijk, P. 1995. "Aristotle on distinguished physicians and the medical significance of dreams." In Ancient Medicine in its Socio-Cultural Context: papers read at the congress held at Leiden University, 13-15 April 1992, Vol. Il, edited by H. F. J. Horstmanshoff, P. J. van der Eijk, and P. H. Schrijvers, 447-59. Amsterdam and Atlanta, GA: Rodopi.

van der Eijk, P. 1999. “On Sterility ('HA X'), a medical work by Aristotle?” Classical Quarterly 49: 490-502.

van der Eijk, P. 2005. "To help, or do no harm. Principles and practices of therapeutics in the Hippocratic Corpus and in the work of Diocles of Carystus." In his Medicine and Philosophy in Classical Antiquity: Doctors and Philosophers on Nature, Soul, Health and Disease, 101-18. Cambridge: Cambridge University Press.

van der Eijk, P. 2017. “The Place of Disease in a Teleological Worldview." In Teleology in the Ancient World: Philosophical and Medical Approaches, edited by J. Rocca, 217-41. Cambridge: Cambridge University Press.

Velleman, J. D. 1992. “Against the Right to Die.” The Journal of Medicine and Philosophy 17: 66581.

Ward, J. 2008. Aristotle on Homonymy: Dialectic and Science. Cambridge: Cambridge University Press.

WHO (World Health Organization). 1946. "Constitution of the World Health Organization." American Journal of Public Health 36(11): 1315-23.

Woods, M. (ed., trans., and comm.). 1992. Aristotle: Eudemian Ethics Books I, II, and VIII, 2nd ed. Oxford: Clarendon Press. 